\title{
Towards a predictive framework for biocrust mediation of plant performance: A meta-analysis
}

\author{
Caroline A. Havrilla, ${ }^{1,2}$ | V. Bala Chaudhary ${ }^{3}$ | Scott Ferrenberg ${ }^{4}$ (D) | \\ Anita J. Antoninka $^{5}$ (D) | Jayne Belnap ${ }^{6}$ (D) | Matthew A. Bowker ${ }^{5}$ (D) | David J. Eldridge ${ }^{7}$ (D) | \\ Akasha M. Faist $^{8}$ (D) | Elisabeth Huber-Sannwald ${ }^{9}$ (D) | Alexander D. Leslie ${ }^{1}$ | \\ Emilio Rodriguez-Caballero $^{10,11}$ (D) | Yuanming Zhang ${ }^{12}$ | Nichole N. Barger ${ }^{1}$ (D)
}

\begin{abstract}
${ }^{1}$ Department of Ecology and Evolutionary Biology, University of Colorado, Boulder, CO, USA; ${ }^{2}$ US Geological Survey, Southwest Biological Science Center, Flagstaff, AZ, USA; ${ }^{3}$ Department of Environmental Science and Studies, DePaul University, Chicago, IL, USA; ${ }^{4}$ Department of Biology, New Mexico State University, Las Cruces, NM, USA; ${ }^{5}$ School of Forestry, Northern Arizona University, Flagstaff, AZ, USA; ${ }^{6}$ US Geological Survey, Southwest Biological Science Center, Moab, UT, USA; ${ }^{7}$ Department of Premier and Cabinet, School of Biological, Earth, and Environmental Sciences, University of New South Wales, Sydney, NSW, Australia; ${ }^{8}$ Department of Animal and Range Sciences, New Mexico State University, Las Cruces, NM, USA; ${ }^{9}$ División de Ciencias Ambientales, Instituto Potosino de Investigación Científica y Tecnológica, San Luis Potosí, Mexico; ${ }^{10}$ Multiphase Chemistry Department, Max Planck Institute for Chemistry, Mainz, Germany; ${ }^{11}$ Estación Experimental de Zonas Áridas (CSIC), Almería, Spain and ${ }^{12}$ Key Laboratory of Biogeography and Bioresources in Arid Land, Xinjiang Institute of Ecology and Geography, Chinese Academy of Sciences, Urumqi, China
\end{abstract}

Correspondence

Caroline A. Havrilla

Email: caroline.havrilla@colorado.edu

Funding information

USGS Ecosystem and Land Change

Sciences Program; DePaul University

College of Science and Health; National

Science Foundation, Grant/Award Number:

DEB-1844531; U.S. Geological Survey;

University of Colorado Boulder, Grant/

Award Number: DGE-1144083; Consejo

Nacional de Ciencia y Tecnología, Grant/

Award Number: SEP-CONACYT 251388

Handling Editor: Franciska de Vries

\section{Abstract}

1. Understanding the importance of biotic interactions in driving the distribution and abundance of species is a central goal of plant ecology. Early vascular plants likely colonized land occupied by biocrusts - photoautotrophic, surface-dwelling soil communities comprised of cyanobacteria, bryophytes, lichens and fungi - suggesting biotic interactions between biocrusts and plants have been at play for some 2,000 million years. Today, biocrusts coexist with plants in dryland ecosystems worldwide, and have been shown to both facilitate or inhibit plant species performance depending on ecological context. Yet, the factors that drive the direction and magnitude of these effects remain largely unknown.

2. We conducted a meta-analysis of plant responses to biocrusts using a global dataset encompassing 1,004 studies from six continents.

3. Meta-analysis revealed there is no simple positive or negative effect of biocrusts on plants. Rather, plant responses differ by biocrust composition and plant species traits and vary across plant ontogeny. Moss-dominated biocrusts facilitated, while lichen-dominated biocrusts inhibited overall plant performance. Plant responses also varied among plant functional groups: $\mathrm{C}_{4}$ grasses received greater benefits from biocrusts compared to $\mathrm{C}_{3}$ grasses, and plants without $\mathrm{N}$-fixing symbionts responded more positively to biocrusts than plants with $\mathrm{N}$-fixing symbionts. Biocrusts decreased germination but facilitated growth of non-native plant species.

This is an open access article under the terms of the Creative Commons Attribution License, which permits use, distribution and reproduction in any medium, provided the original work is properly cited.

(C) 2019 The Authors. Journal of Ecology published by John Wiley \& Sons Ltd on behalf of British Ecological Society. 
4. Synthesis. Results suggest that interspecific variation in plant responses to biocrusts, contingent on biocrust type, plant traits, and ontogeny can have strong impacts on plant species performance. These findings have important implications for understanding biocrust contributions to plant productivity and community assembly processes in ecosystems worldwide.

\section{KEYWORDS}

biological soil crust, biotic interactions, biotic resistance; biotic soil community; germination, facilitation, meta-analysis, plant functional traits, plant-soil (below-ground) interactions

\section{1 | INTRODUCTION}

Understanding the predictors of species distribution and abundance has long been a central goal of ecology (e.g. Callaway, 2007; Oosting, 1948). While there is wide consensus of the primary importance of dispersal limitations and barriers posed by the abiotic environment in predicting species distribution and abundance patterns (e.g. Cornwell \& Ackerly, 2009; Keddy, 1992; Kraft, Adler, et al., 2015), ecologists continue work to understand how local, biotic interactions restrict or enhance species performance. Positive (facilitative) and negative (competitive) species interactions can determine key attributes of ecosystems such as the number of species, their distribution, and the range of species traits present within communities (Boulangeat, Gravel, \& Thuiller, 2012; Michalet et al., 2006; Wisz et al., 2013). Accordingly, biotic interactions are increasingly being incorporated into community theory (Brooker et al., 2008; Bruno, Stachowicz, \& Bertness, 2003; HilleRisLambers, Adler, Harpole, Levine, \& Mayfield, 2012; Lortie et al., 2004) and predictions of how communities will respond to global change (Brooker et al., 2008; He, Bertness, \& Altieri, 2013; McCluney et al., 2012; Staniczenko, Sivasubramaniam, Suttle, \& Pearson, 2017; Van Der Putten, Macel, \& Visser, 2010). In plant community ecology, the role of plant-plant interactions in determining plant species performance and community composition have been frequently tested (Levine, Adler, \& Yelenik, 2004; Noble \& Slatyer 1977; Tilman, 2004). In contrast, the importance of soil biotic communities in determining plant species performance has been historically less studied, but evidence indicates a strong influence on plant community structure and productivity (Bever et al., 2010; Hortal et al., 2017; Van Der Heijen, Bardgett, \& Van Straalen, 2008).

Biological soil crusts (biocrusts) - biotic soil surface communities comprised of varying assemblages of cyanobacteria, algae, bryophytes, lichens and fungi - occupy the top few millimeters of the soil surface in dryland ecosystems globally (Belnap, Weber, \& Büdel, 2016). Fossil data suggest early biocrusts began their colonization of Earth's terrestrial surface some 2,500 million years ago (Beraldi-Campesi, 2013), predating the evolution of seed plants by at least 2,000 million years (Kenrick \& Crane, 1997). This suggests that, during their colonization of dry land, early vascular plant (hereafter 'plant') communities likely encountered biocrusts, and that biotic interactions between biocrusts and plants may have been playing out for millennia. Today, biocrusts are estimated to cover $12 \%$ of the Earth's terrestrial surface (Rodriguez-Caballero et al., 2018), and are particularly widespread in dryland ecosystems, which comprise 45\% of global landmass (Prăvălie, 2016). As biocrusts and plants continue to coexist in ecosystems worldwide, we are offered a unique opportunity to study the impacts of biocrusts on plant performance in present-day communities where biocrusts and plants co-occur.

Abundant evidence suggests biocrusts can be key mediators of plant species performance. Biocrusts occur in patchy mosaics alongside adjacent patches of uncrusted soil and vegetation, creating habitat and soil resource heterogeneity through physical and chemical modifications of the soil environment (Concostrina-Zubiri, Huber-Sannwald, Martínez, Flores, \& Escudero, 2013). Where they occur, biocrusts positively influence soil structure and physical stability (Belnap \& Büdel, 2016; Bowker, Belnap, Chaudhary, \& Johnson, 2008; Zhang, Wang, Wang, Yang, \& Zhang, 2006). Biocrusts are also key intermediaries of nutrient cycling, accounting for $15 \%$ of global terrestrial carbon (C) and $\sim 40 \%-85 \%$ of nitrogen ( $N$ ) fixation globally (Rodriguez-Caballero et al., 2018). As such, biocrusts enhance soil fertility by increasing the availability of C (Li, Zhang, Su, \& Jia, 2012; Tucker et al., 2017) and N (Barger, Weber, Garcia-Pichel, Zaady, \& Belnap, 2016) as well as other mineral nutrients (Belnap \& Harper, 1995; Concostrina-Zubiri et al., 2013; Guo, Zhao, Zuo, Drake, \& Zhao, 2008; Jafari et al., 2004). Biocrusts additionally modify soil microclimate via alteration of soil hydrology (Belnap, 2006; Chamizo, Belnap, Eldridge, Cantón, \& Issa, 2016; Concostrina-Zubiri, Molla, Velizarova, \& Branquinho, 2017; Faist, Herrick, Belnap, Van Zee, \& Barger, 2017) and surface temperature (Concostrina-Zubiri et al., 2017; Couradeau et al., 2016). Given this wide range of soil modifications, biocrusts can strongly impact the recruitment and performance of plant species with which they coexist (Belnap, Prasse, \& Harper, 2003; Zhang, Aradottir, Serpe, \& Boeken, 2016).

In recent decades, a growing number of individual studies have investigated biocrust effects on plant species performance worldwide (Belnap et al., 2003; Zhang et al., 2016). Evidence suggests biocrust effects on plant species can be facilitative (DeFalco, Detling, Tracy, \& Warren, 2001; Godínez-Alvarez, Morín, \& RiveraAguilar, 2012; Lesica \& Shelly, 1992; Zhang \& Nie, 2011), neutral 
(Godínez-Alvarez et al., 2012; Megill, Walker, Vanier, \& Johnson, 2011), or inhibitory (Eldridge, Zaady, \& Shachak, 2000; Zaady, Gutterman, \& Boeken, 1997; Zhang, Nan, BingChang, \& Jing, 2010), depending on the ecological context in which they are studied. Moreover, empirical work has demonstrated biocrusts may affect plant community assembly and coexistence in situ (Chung \& Rudgers, 2016; Luzuriaga, Sánchez, Maestre, \& Escudero, 2012) and can increase or decrease plant community diversity (Breen \& Levesque, 2006; Lan, Wu, Zhang, \& Hu, 2013; Miller \& Damschen, 2017; Peralta, Sánchez, Luzuriaga, \& Escudero, 2016; Scott \& Morgan, 2012). The circumstances in which the influence of biocrusts on plants can be generalized as negative or beneficial is less well understood, as well as the relative importance of key moderators (e.g. plant traits, environmental conditions) in driving interspecific variability in plant responses to biocrusts. As such, context-dependency in plant responses to biocrusts remain poorly understood, given the narrow spatiotemporal and taxonomic focus of most individual studies.

Functional traits capture essential aspects of species' ecophysiology, morphology, and life history strategies, and are thus often important predictors of interspecific variation in outcomes of biotic interactions (Ackerly \& Cornwell, 2007; Kraft \& Ackerly, 2014; Kraft, Godoy, \& Levine, 2015; Lavorel \& Garniel, 2002; Kunstler et al., 2016; Lebrija-Trejos, Pérez-García, Meave, Bongers, \& Poorter, 2010; McGill, Enquist, Weiher, \& Westoby, 2006). Given the speciesspecificity of plant responses to biocrusts and the general importance of plant functional traits in determining biotic interactions, we hypothesize that plant functional traits, especially those associated with acquisition of limiting resources (e.g. water, nutrients), mediate plant responses to biocrusts. These include plant functional groups, which encompass species' life form, photosynthetic pathway, and presence of $\mathrm{N}$-fixing symbionts, as well as plant duration, and root morphology. Moreover, observations that biocrusts can increase native plant species performance while inhibiting that of non-native species have generated considerable interest in the potential of biocrusts to contribute to the biotic resistance of plant communities (Briggs \& Morgan, 2011; Gelbard \& Belnap, 2003; Havrilla \& Barger, 2018; Hernandez \& Sandquist, 2011; Peterson, 2013; Reisner, Grace, Pyke, \& Doescher, 2013).

Biocrust community composition may also determine effects on plant species given biocrust type largely determines the magnitude of biocrust contributions to soil hydrology, and $\mathrm{C}$ and $\mathrm{N}$ cycling (Barger et al., 2016; Bowker, Mau, Maestre, Escolar, \& Castillo-Monroy, 2011; Chamizo, Cantón, Miralles, \& Domingo, 2012). Finally, community theory predicts biotic interactions may differentially influence species performance and trait organization along environmental gradients as resource limitations shift (Cornwell \& Ackerly, 2009; He et al., 2013; Maestre et al., 2010), and the importance of niche-based processes increases with increasing abiotic stress (Bruno et al., 2003; Gross, Liancourt, Choler, Suding, \& Lavorel, 2010; Liancourt, Callaway, \& Michalet, 2005). As such, we posit that the magnitude and direction of plant responses to biocrusts may also be mediated by the ecosystem of origin of study organisms and disturbance.
To address knowledge gaps concerning the outcomes and predictors of plant responses to biocrusts, we compiled a global database of biocrust-plant interaction literature and employed meta-analytical techniques to synthesize global patterns in existing data. Our specific research objectives were to assess the overall effects of biocrusts on plants, document what ecological moderators are most influential in determining the magnitude and direction of these effects and identify remaining knowledge gaps and provide recommendations for future research. Specifically, we tested the propositions that (a) biocrust community composition mediates the direction and strength of plant responses to biocrusts, (b) biocrust effects on plants are not uniformly experienced by all plant types but vary depending on plant characteristics and functional traits, and (c) plant responses to biocrusts shift depending on abiotic environmental conditions (e.g. organisms' ecosystem of origin, disturbance).

Results from this meta-analysis are expected to have broad implications for understanding the effects of biocrusts on plant species performance. In turn, this knowledge will allow incorporation of biocrusts into broader plant community theory and ecosystem management practices. Moreover, given that global landcover of biocrust communities is expected to decline $20 \%-40 \%$ within the next 65 years in response to climate change and land use intensification (Rodriguez-Caballero et al., 2018), and local biocrust community structure may also shift in response to climate change (Ferrenberg, Reed, \& Belnap, 2015; Reed et al., 2012), we believe it is critical and timely to examine relationships between biocrusts and plant communities to better understand how the ecosystems in which they co-occur will respond to global change.

\section{2 | MATERIALS AND METHODS}

\section{1 | Literature search and database construction}

To populate our global dataset, we searched the ISI Web of Science database (http://www.webofknowledge.com/) and records from 1940 to 2017 in the Chinese National Knowledge Infrastructure (CNKI) Digital Learning Platform (http://www.cnki.net/) for Chinese records not available in English), using all possible combinations of keywords for biocrust (i.e. [biological soil crust, biocrust, cryptobiotic soil crust, cryptogamic soil crust, and microbiotic soil crust] * plant responses [plant] * [germination, survival, growth, cover, nutrient uptake, phenology, reproduction and diversity]) to generate the set of records to be considered. We then employed a systematic screening process to retain or exclude articles for this meta-analysis (Figure S1). Eligible articles were defined as those including any comparison ('study') of the performance of plants grown in the presence of biocrusts to plants that were grown in biocrust-absent controls (i.e. bare soil, biocrust removal, or biocrust disturbance). We retained articles that quantified the impacts of biocrusts on plant performance variables (i.e. germination, survival, growth, cover, nutrient uptake, phenology and diversity) in observational or experimental settings, omitting studies that considered the effects of plants on biocrust communities. Individual articles often yielded multiple studies: for example, if 
a study compared multiple responses (e.g. germination and growth) of multiple plant species to biocrust presence, each plant response and species was considered separately, but given a unique numerical identifier to later test for non-independence.

From each study, we collected data on plant response variables in the presence and absence of biocrusts, as well as eight study characteristics (i.e. BIOCRUST_TYPE, ECOSYSTEM_OF_ORIGIN, PLANT_FUNCTIONAL_GROUP, PLANT_NATIVENESS, PLANT_ DURATION, PLANT_ROOT_MORPHOLOGY, SOIL_REFERENCE_ STATE, STUDY_LOCATION; Table 1) used as moderators in our multi-factor meta-analysis. We recorded the mean (X), standard deviation (SD), standard error (SE), and sample size (n) of both the biocrust and biocrust-absent (control) plots for the plant response variables. Data were extracted directly from tables, published supplementary materials, and from digitized figures using "xyscan" version 4.2 .1 (http://rhig.physics.yale.edu/ ullrich/softw are/xyscan/). A detailed description of our data extraction protocol is summarized in Appendix S1.

\subsection{Calculation of meta-analysis metrics}

\subsection{1 | Effect size}

For each biocrust-present and absent comparison, we calculated an effect size for each plant response variable using mean values.
In addition, to investigate biocrust effects on 'overall plant performance', we estimated an overall effect size (and within-study variance; see below) for plant performance by averaging the effect sizes of all plant responses reported for each reported plant species. Specifically, the effect size of biocrust presence was calculated as the log response ratio: $\ln \left(X_{\text {crust }} / X_{\text {ctrl }}\right)$, where $X_{\text {crust }}$ is the mean plant response in the biocrust treatment, and $X_{c t r l}$ is the mean plant response in the biocrust-absent control. When positive, this metric indicates that biocrusts have a beneficial influence on the plant response of interest and when negative, a detrimental influence. Log response ratios provide a standardized measure of plant performance with favorable statistical properties for meta-analysis (Hedges, Gurevitch, \& Curtis, 1999) and means for comparisons among studies with different plant response metrics.

\subsection{2 | Within-study variance}

To account for differences in study precision, we weighted our analysis by estimating within-study variance for each study as in Hedges et al. (1999). Specifically, the within-study variance used in our weighted regressions was calculated as follows:

$$
\sigma^{2}=\left[\frac{S D_{\text {crust }}^{2}}{\left(n_{\text {crust }}\right)\left(X_{\text {crust }}^{2}\right)}\right]+\left[\frac{S D_{\text {ctrl }}^{2}}{\left(n_{\text {ctrl }}\right)\left(X_{\text {ctrl }}^{2}\right)}\right],
$$

TAB LE 1 The eight, candidate categorical fixed-effect moderators explored in our mixed-effects meta-analyses

\begin{tabular}{|c|c|c|}
\hline Explanatory variable & $\begin{array}{l}\text { Number } \\
\text { of levels }\end{array}$ & Description of variable levels \\
\hline BIOCRUST_TYPE & 4 & $\begin{array}{l}\text { Cyanobacteria, Moss, Lichen, Mixed; Classified by the dominant biocrust taxonomic group in the } \\
\text { biocrust community as reported in the study. 'Mixed' biocrusts are communities containing sub- } \\
\text { stantial cover of both mosses and lichens. }\end{array}$ \\
\hline ECOSYSTEM_OF_ORIGIN & 5 & $\begin{array}{l}\text { Hyper-Arid, Arid, Semi-Arid, Dry Sub-humid, Other; Ecosystem type is based on the aridity index } \\
(\mathrm{Al})^{\mathrm{a}} \text { of the location from which the biocrust community originated in order of greatest to least } \\
\text { aridity: Hyper-arid }(\mathrm{Al}<0.05) \text {; Arid }(0.05<\mathrm{Al}<0.20) \text {; Semi-arid }(0.20<\mathrm{Al}<0.50) \text {; Dry sub-humid } \\
(0.50<\mathrm{Al}<0.65) \text {; Other }(\mathrm{Al}>0.65) \text {. }\end{array}$ \\
\hline $\begin{array}{l}\text { PLANT_FUNCTIONAL_ } \\
\text { GROUP }\end{array}$ & 7 & $\begin{array}{l}\mathrm{C}_{3} \text { grass, } \mathrm{C}_{4} \text { grass, } \mathrm{N} \text {-fixing forb, Non- } \mathrm{N} \text {-fixing forb, } \mathrm{N} \text {-fixing woody plant, Non- } \mathrm{N} \text {-fixing woody } \\
\text { plant, and Community; Plant functional group as designated in herbarium record for plant species. } \\
\text { 'Community' designates multiple plant species belonging to multiple plant functional groups. }\end{array}$ \\
\hline PLANT_NATIVENESS & 3 & $\begin{array}{l}\text { Native or Non-Native; Corresponding to the native status of the plant in the study region. Non- } \\
\text { Native species include any species not native to the study region }\end{array}$ \\
\hline $\begin{array}{l}\text { PLANT_ROOT_ } \\
\text { MORPHOLOGY }\end{array}$ & 3 & $\begin{array}{l}\text { Fibrous, Tap, or Community; Designated based on herbarium records. 'Community' designates } \\
\text { multiple plant species with a combination of tap and fibrous root morphologies. }\end{array}$ \\
\hline PLANT_DURATION & 3 & $\begin{array}{l}\text { Annual, Perennial, or Community; As designated in herbarium records. 'Community' designates } \\
\text { multiple plant species with a mix of annual and perennial species. }\end{array}$ \\
\hline SOIL_REFERENCE_STATE & 4 & $\begin{array}{l}\text { Bare soil, Biocrust removal, Biocrust disturbance, or Filter paper; Experimental control soil sub- } \\
\text { strate for comparison to biocrust treatment as recorded in the study. 'Biocrust removal' controls } \\
\text { are those in which biocrust organisms have been removed from the soil surface while 'biocrust } \\
\text { disturbance' controls are those that have been mechanically disturbed or trampled. }\end{array}$ \\
\hline STUDY_LOCATION & 2 & Field or Greenhouse; Corresponding to the experimental setting of the study. \\
\hline
\end{tabular}

${ }^{a}$ Aridity index (Al) was calculated as the average yearly precipitation divided by average yearly potential evapotranspiration, an aridity index defined by the United Nations Environmental Program (UNEP). The input data used to calculate this dataset are part of the "CRU CL 2.0 Global Climate Dataset" prepared by the Climate Research Unit of the University of East Anglia, UK (New, Lister, Hulme, \& Makin, 2002), and distributed through the website: http://www.cru.uea.ac.uk/ timm/grid/CRU_CL_2_0.html). 
where $X_{\text {crust }}$ and $X_{\text {ctrl }}$ are the mean plant response with and without in biocrust, $S D_{\text {crust }}$ and $S D_{\text {ctrl }}$ are the standard deviation of treatment and control means, and $n_{\text {crust }}$ and $n_{\text {ctrl }}$ are the number of replicates with biocrust versus biocrust-absent soil treatments, respectively. If no measure of variance was reported for a study (SD or SE; $20.8 \%$ of studies), we used imputation to calculate missing variances in our dataset (Nakagawa, 2015) using Taylors Law, the relationship between mean and variance (for of our dataset $\left(\log \left(S D_{\text {pooled }}\right)=(\log (X-\right.$ pooled $) * 0.7998)-0.5236 ; R^{2}=0.73$ ).

\section{3 | Boosted regression tree data exploration}

To explore the relative importance of the candidate moderators and their potential interactions in explaining variation among plant response to biocrusts, we performed boosted regression tree (BRT) analyses on candidate variables in each of the five plant response models (Table 1; Table S1a). Boosted regression tree analysis additively fits and combines multiple trees using a forward stepwise procedure, thus improving accuracy (De'Ath, 2007). BRT analysis is ideal for complex data and unidentified distributions (De'Ath, 2007), and additionally, can accommodate missing values in moderators (De'Ath, 2007; Elith, Leathwick, \& Hastie, 2008).

We performed BRTs using the 'gbm.step' function in the gbm (Ridgeway, Southworth, \& Runit, 2013) and dismo packages (Hijmans, Phillips, Leathwick, \& Elith, 2017) as in Elith and Leathwick (2017). This and all subsequent statistical analyses in this study were conducted in the R open-source software environment (version 3.3.3; R Core Development Team, 2017). In each BRT model, we included only those moderators that had sufficient representation in the dataset and corresponded to meaningful a priori hypotheses (Figure S1a); we then weighted each analysis according to the within-study variance. Models were simplified using the 'gbm.simplify' function suggested by Elith and Leathwick (2017). Simplified BRT models for each analysis included the most influential moderators and ranked them according to their relative contributions (which are scaled to sum to $100 \%$ within each model-i.e. the moderator explains $X \%$ of the variation explained by the fitted BRT) to the explanation of variation in effect size. Relative variable influences were derived as an average of variable influence in all trees in each BRT model (Friedman \& Meulman, 2003). Potential interactions between moderators in final BRT models were explored using the 'gbm.interaction' function (Elith \& Leathwick, 2017).

\section{4 | Mixed multi-factor meta-analysis}

Following the selection of key moderators to be retained in each of the five plant variable response models via BRT, meta-analyses were performed by fitting mixed-effects meta-regression models using the rma.mv function from the metafor package (Viechtbauer, 2010) with restricted maximum likelihood estimation of parameters. We first used pure random effects models to estimate the overall weighted mean effect size for each plant response model (i.e. the weighted, overall log response ratios of the plant response variables to biocrust presence; Table 2), with each effect size weighted by within-study variance and

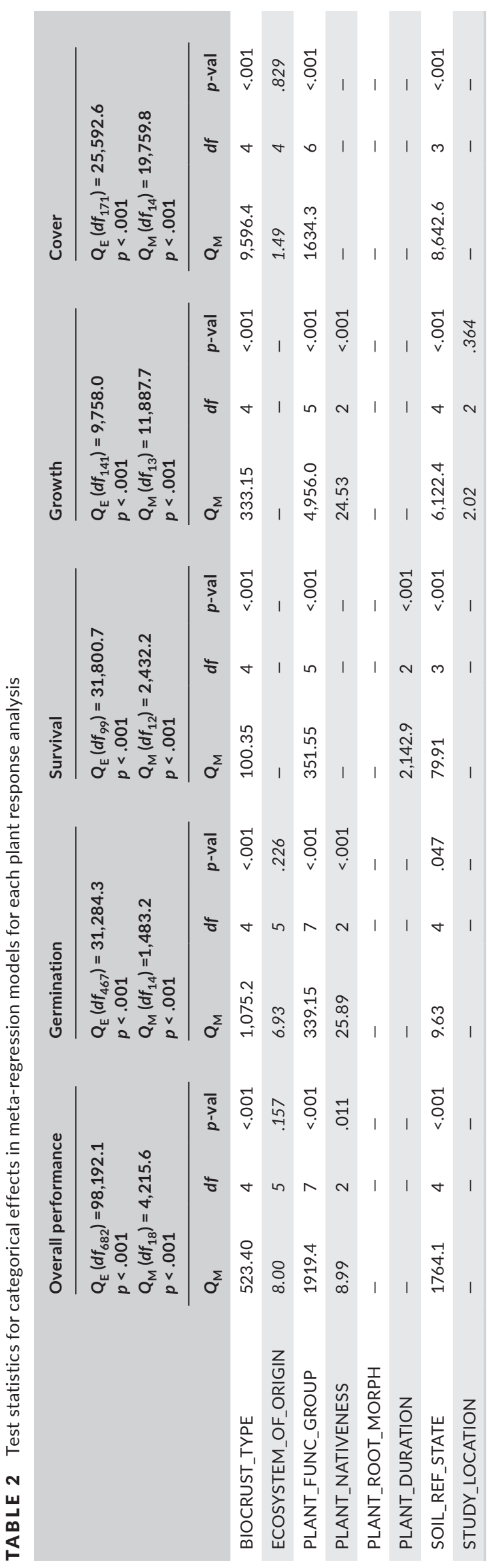


the residual between-study variance component ('STUDY_ID') as a random-effect variable. Then, for each of the five separate analyses, we investigated the relative importance of the categorical fixed-effect moderators (Table 1) included in each model (Table S1b, Figure 1) by analyzing a series of mixed-effect multiple meta-regression models, including a global model containing all the fixed factors (moderators) being considered for that dataset and each of the nested subset models containing one more fixed factor. Every model also contained the random effect STUDY_ID to account for residual between-studies variation. When categorical moderators were significant ( $Q$ statistic < 0.05), differences in moderator levels were detected using planned contrasts with the 'linearHypothesis' function from the car package (Fox \& Weisberg, 2011). To explain residual heterogeneity and understand the potential effect of contextual factors on plant responses to biocrusts, we ran a series of separate univariate metaregression models for each analysis that included single significant moderators. Interaction terms were only fitted in models if found to be influential in simplified BRT models. Parameters associated with moderators with non-significant effects are not depicted graphically.

\section{3 | RESULTS}

\section{1 | Database summary}

We retained 1,004 usable studies from 75 unique articles in our final database after our iterative screening process (Figure S1; Appendix S1). Of these, most studies focused on biocrust effects on seedling germination ( $n=491 ; 48.9 \%$ of studies), followed by effects on plant cover $(n=231 ; 23.0 \%)$, growth $(n=159 ; 15.8 \%)$, and survival $(n=123$; $12.3 \%$ ). Our database search did not yield sufficient articles to analyse biocrust effects on plant nutrient uptake, reproductive output, or community diversity. Articles included in our database were published between 1942 and 2017 and studies spanned six continents, with over a third of studies conducted between 30 and 50 degrees in latitude, being mainly in China (42.4\%) and North America (34.6\%). Studies were also included in lesser numbers from Europe (14.8\%), Australia (5.3\%), South America (2.8\%), and Africa (0.59\%; Figure 1). With these studies, we evaluated the response to biocrusts in a total of 171 plant species occurring in 40 plant families.

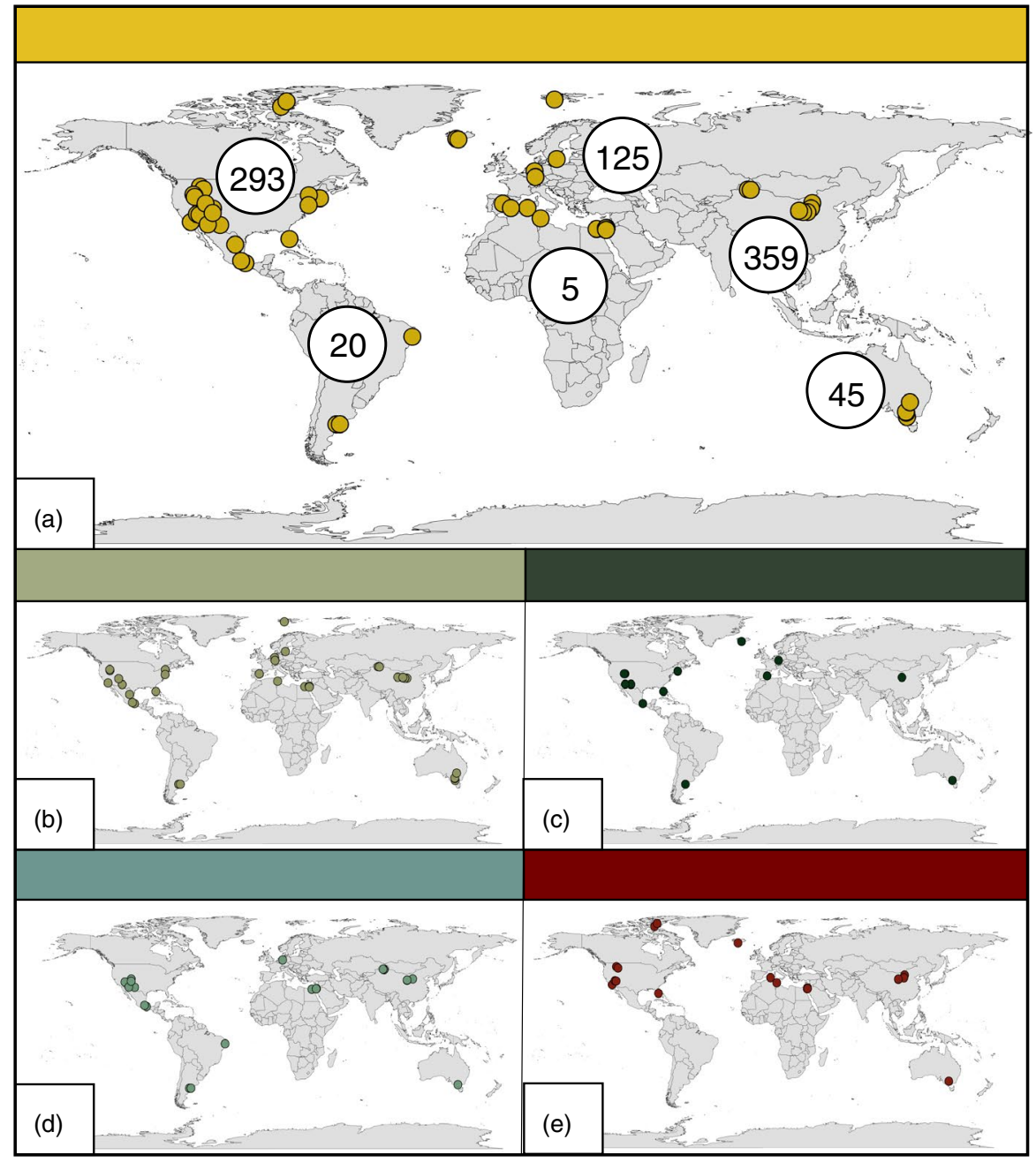

FIGURE 1 Map of locations of studies incorporated into each of the five, separate plant response analyses: (a) overall performance ( $N=847$ studies), (b) germination ( $N=491$ studies), (c) survival ( $N=123$ studies), (d) growth ( $N=159$ studies), and (e) cover $(N=231$ studies). Numbers in panel "a" (overall performance) denote the total number of studies incorporated in this meta-analysis from North America, South America, Europe, Africa, Asia, and Australia respectively [Colour figure can be viewed at wileyonlinelibrary.com] 


\section{2 | BRT data exploration}

Across analyses, the candidate variables with the most explanatory power were BIOCRUST_TYPE (overall plant performance and cover), PLANT_FUNCTIONAL_GROUP (germination and growth), and PLANT_DURATION (survival). Overall, BIOCRUST_ TYPE, PLANT_FUNCTIONAL_GROUP, PLANT_NATIVENESS, SOIL_REFERENCE_STATE, and ECOSYSTEM_OF_ORIGIN were most commonly identified as important moderators in simplified BRT models (Figures 2-4), while PLANT_ROOT_ MORPHOLOGY, PLANT_DURATION, and STUDY_LOCATION were unimportant. Importantly, BRT analyses identified no significant interactions among moderators in any of the plant response models. A lack of influential interaction terms among main effects in simplified BRT models could suggest that interactions were unimportant. However, it could also suggest that our dataset did not contain adequate sample size to assess the importance of these interactions as it can often take a substantially greater sample size to assess interaction terms relative to main effects in mixed-effects regression models (e.g. Leon \& Heo, 2009). Following BRT identification, strong moderators identified for the five plant models were included in mixed multi-factor meta-analyses (Table S1b). Results for final simplified BRT models are summarized in Figure 2 and in additional detail in Appendix S3.

\section{3 | Mixed multi-factor meta-analysis}

Overall mean effect sizes for plant responses to biocrusts were not statistically different from zero (Overall plant performance; $-2.0 \% . p=.891$; Figures 3 and 5$)$, germination $(-5.5 \% ; p=.530$; Figures 3 and 5), survival (-44.2\%; $p=.406$; Figures 3 and 5 ), growth (+27.0\%; $p=.074$; Figures 3 and 5$)$, and cover $(-0.10 \%$; $p=.978$; Figures 3 and 5). However, meta-regression revealed plant germination, survival, growth, and cover responses to biocrusts in the five models were highly context-dependent, as they were mediated by biocrust community composition, plant species traits, and disturbance.

\section{Overall performance}

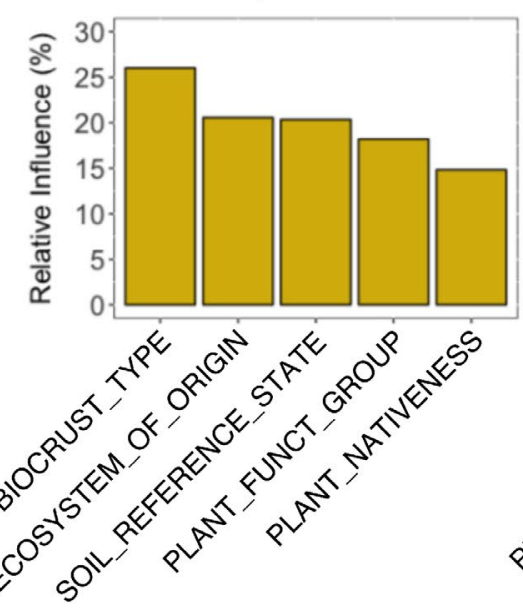

Growth
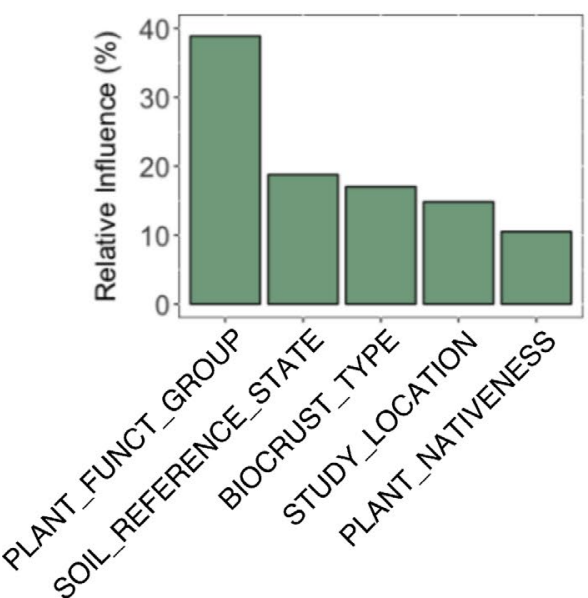

Germination
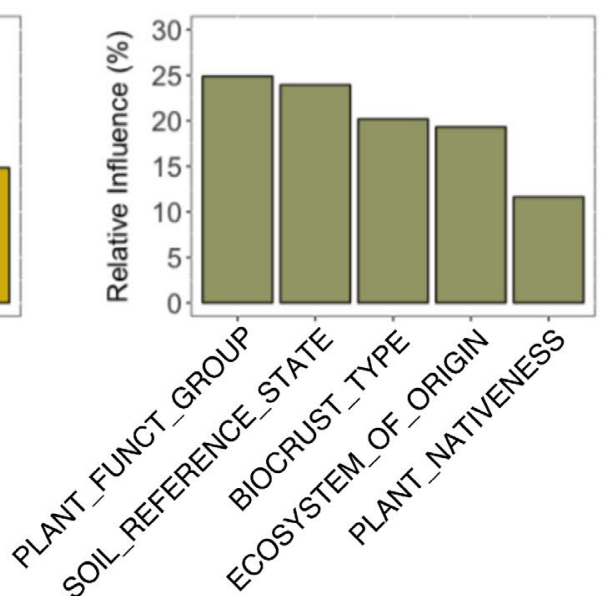

Cover
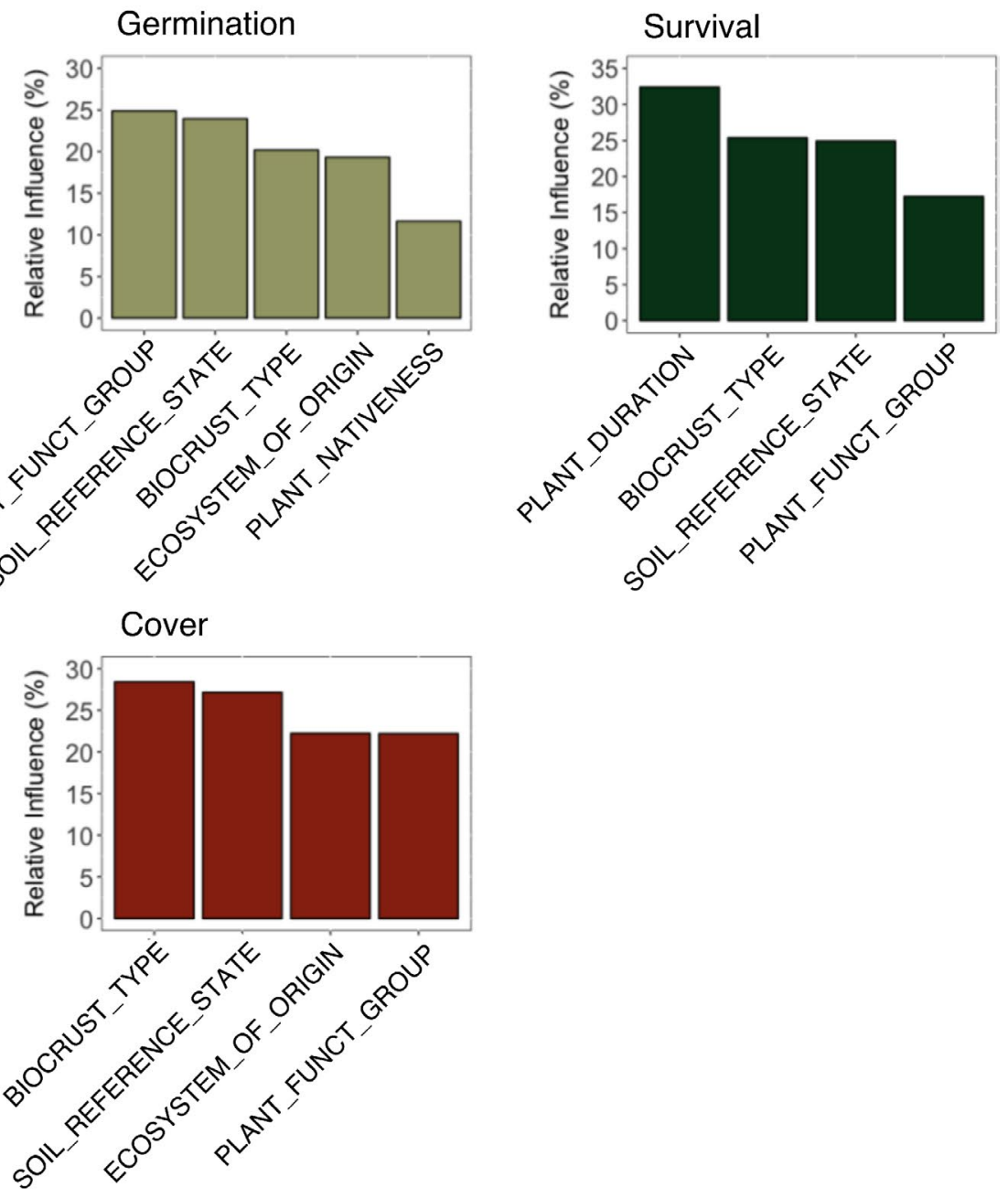

FIGURE 2 Simplified boosted regression tree (BRT) results showing the relative contributions of candidate categorical moderators in percentage on the log responses plants to biocrust presence: overall plant performance, germination, survival, growth, and cover. Influential moderators from BRT's were incorporated into meta-analyses and meta-regression models [Colour figure can be viewed at wileyonlinelibrary.com] 
(I) Overall Performance
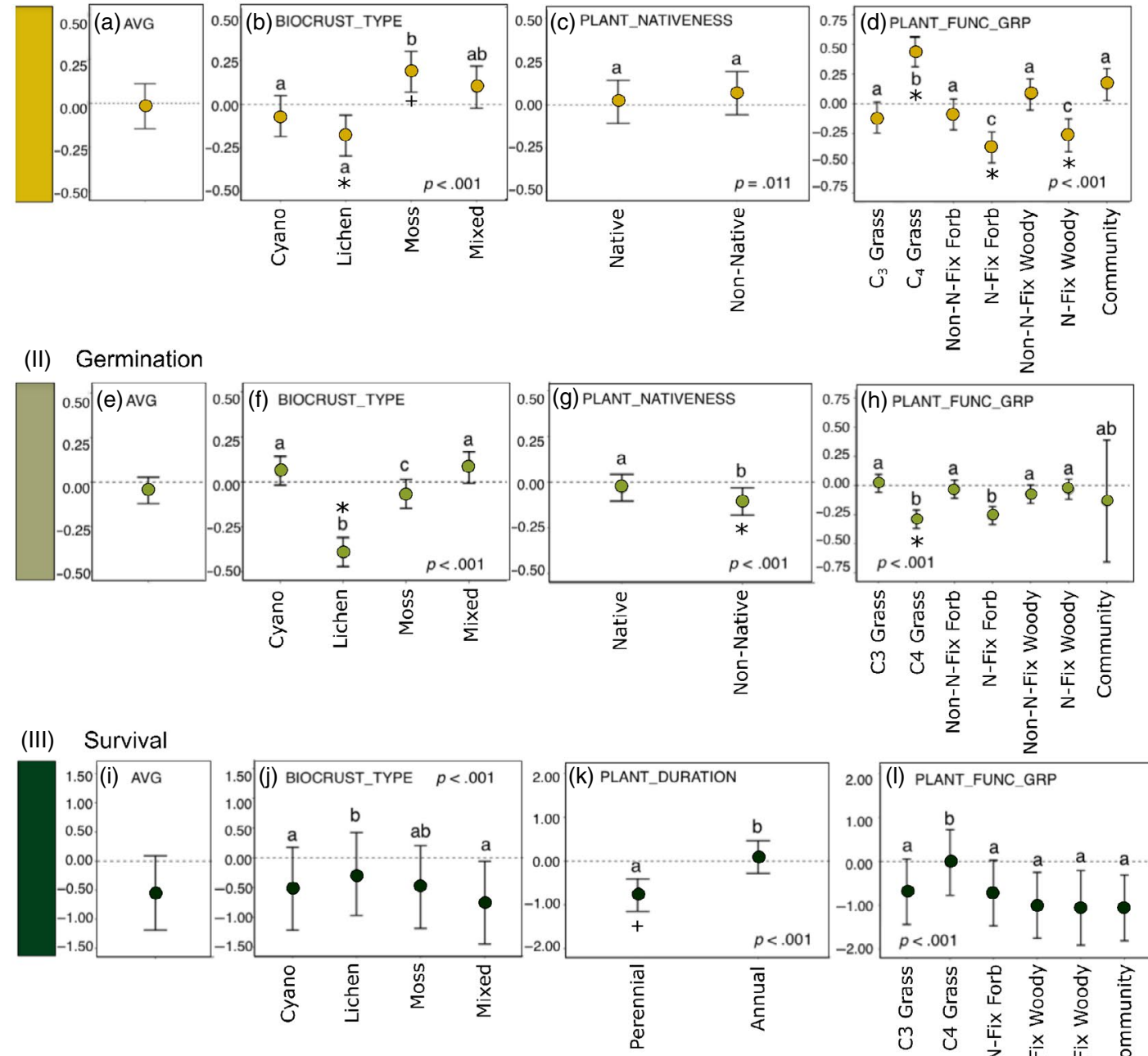

(IV) Growth
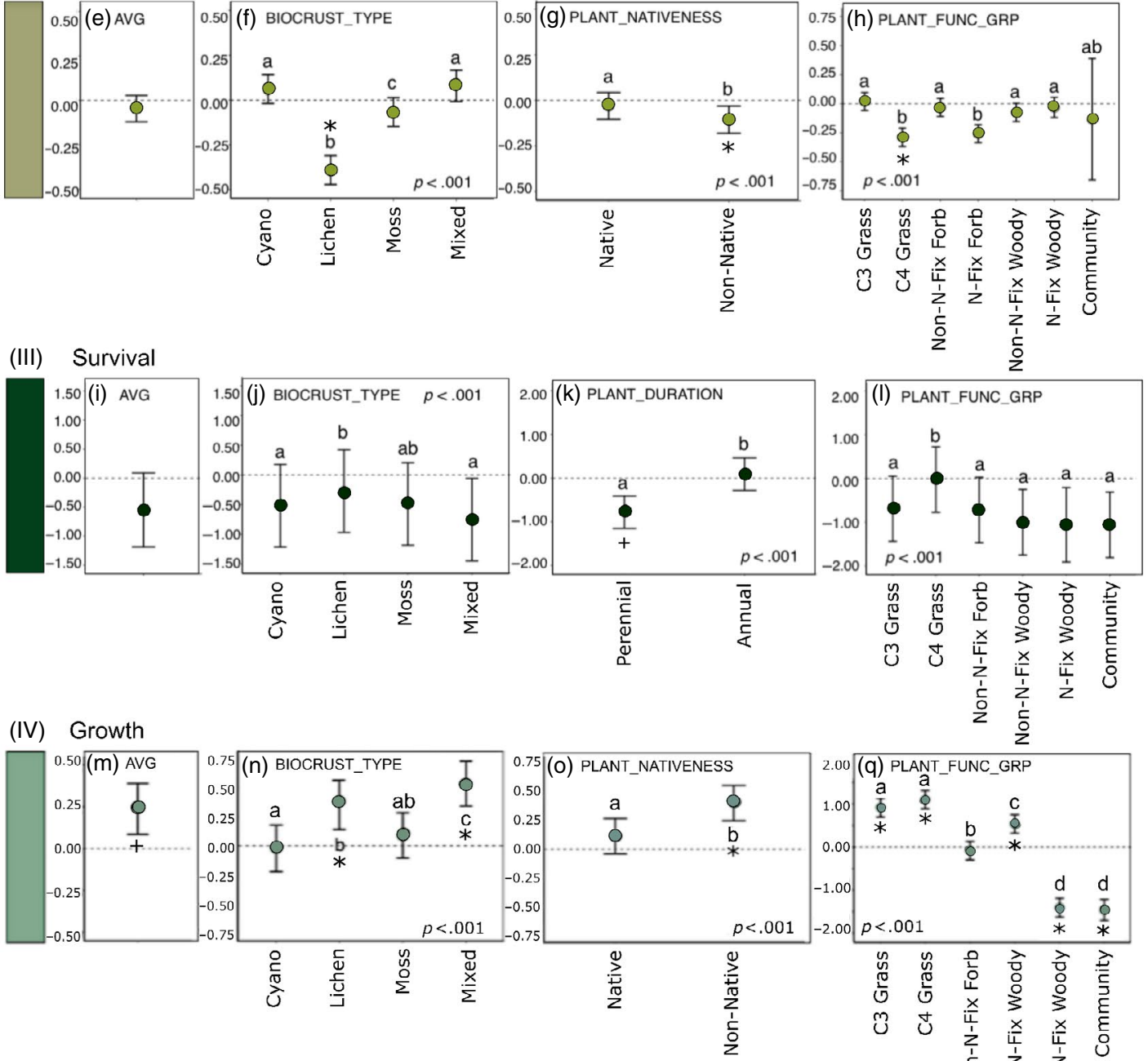

(IV) Cover
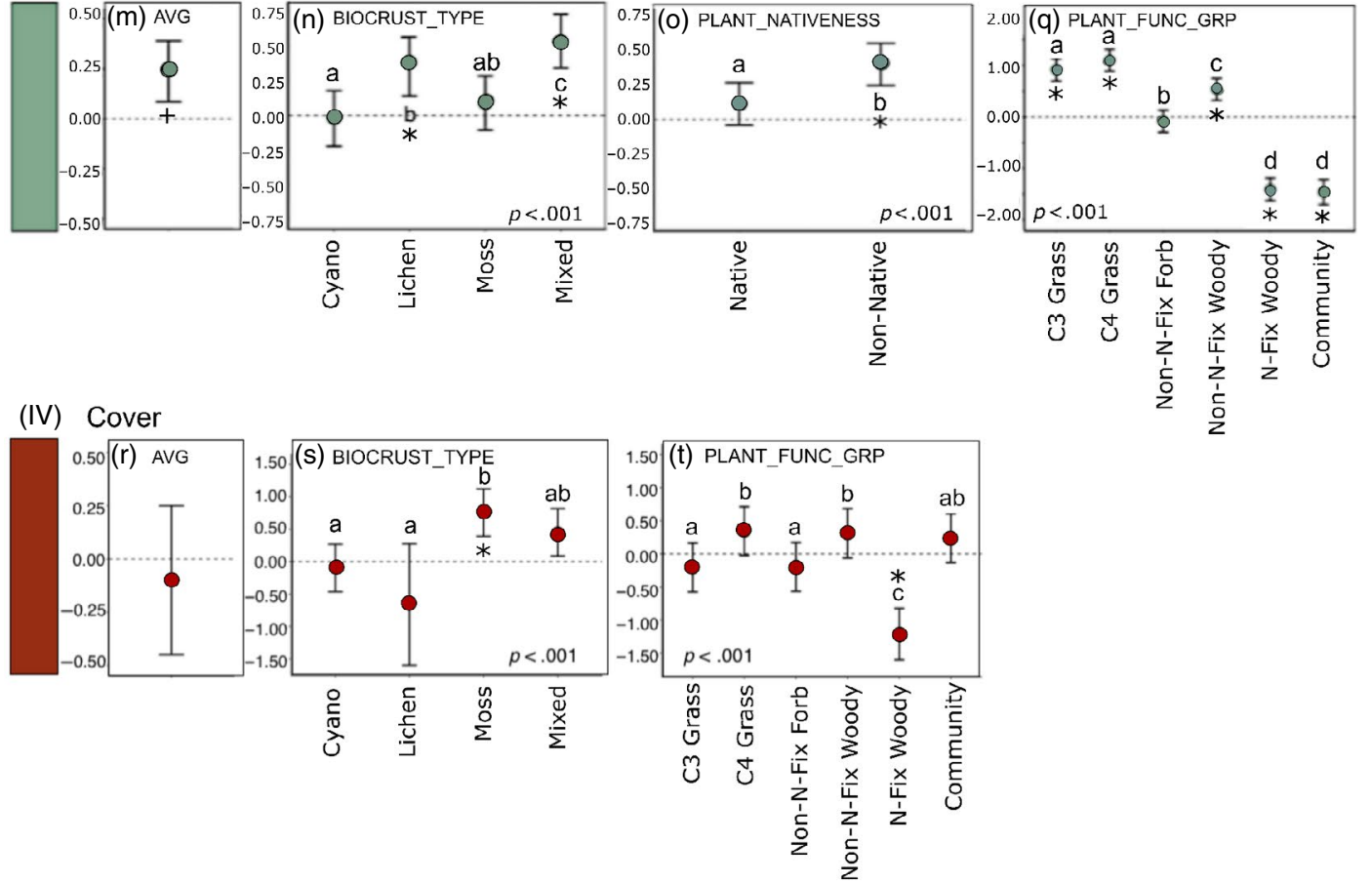
FIGURE 3 Plant performance responses to biocrusts (weighted mean \pm SE): (a) overall plant response ("AVG"), and the three important moderators of this model: (b) BIOCRUST_TYPE, (c) PLANT_NATIVNESS, and (d) PLANT_FUNCTIONAL_GROUP. The number of studies in each moderator group level are shown in parentheses. The $p$-value in the corner of each graph denotes the statistical significance of the explanatory variable in the plant performance model. Lowercase letters denote statistically significant pairwise differences between moderator levels at $p<.05$, and "*" and " + " denote the effect size of a given moderator level is statistically different from zero at $p<.05$ or $0.10>p>.05$ respectively [Colour figure can be viewed at wileyonlinelibrary.com]

\subsection{1 | Biocrust community composition}

BIOCRUST_TYPE was consistently an important predictor of plant responses across plant response models. Biocrust community composition influenced overall plant performance $(p<.001$; Table 2; Figures 3 and 5). Lichen biocrust communities marginally reduced average overall plant performance by $16 \%$ ( $p=.098$; Figure 3 ), while moss biocrusts increased performance by $21 \%$ ( $p=.092$; Figure 3 ). Biocrust community composition also influenced plant germination $(p<.001$; Table 2). Lichen biocrusts reduced seed germination by $32 \%$ ( $p .001$; Figure 3 ), whereas cyanobacterial, moss, and taxonomically mixed biocrusts had neutral effects on plant germination responses overall (Figure 3). Plant survival was also influenced by biocrust type ( $p<.001$; Table 2; Figure 3). While mean effect size for plant survival was negative across biocrust types, no individual biocrust type's mean was significantly different from zero (Figure 3). Planned contrasts, however, showed lichen biocrusts had lesser negative effects on plant survival than cyanobacterial or taxonomically mixed biocrusts (Figure 3). BIOCRUST_TYPE was again significant in determining plant growth ( $p<.001$; Table 2; Figure 3 ), with lichen and mixed biocrust communities increasing plant growth by $47 \%$ ( $p=.098$; Figure 3 ) and 71\% ( $p=.006$; Figure 3 ) respectively. Finally, BIOCRUST_TYPE also predicted plant cover responses $(p<.001$; Table 2, Figure 3) with moss and mixed biocrusts corresponding to plant cover increases of $112 \%$ (Figure 3 ) and $57 \%(p<.001$; Figure 3 ) respectively.
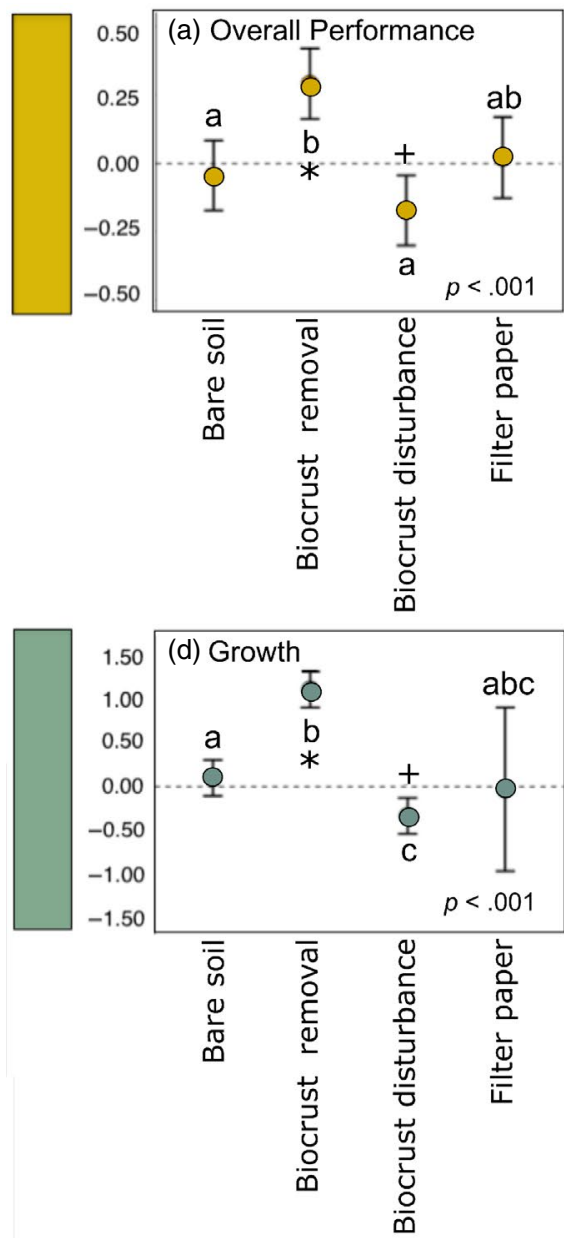

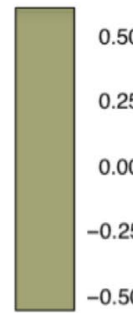

(b) Germination
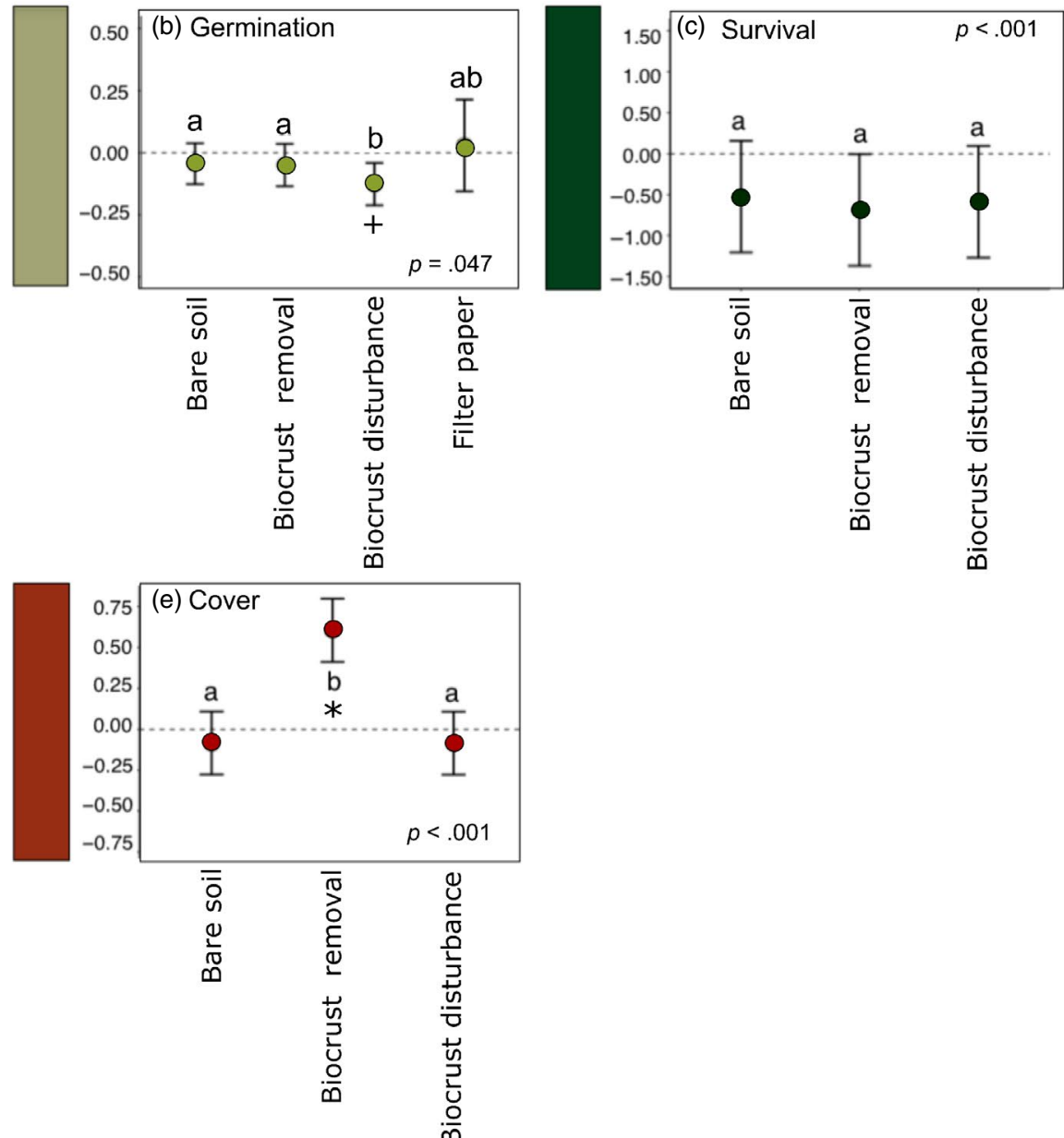

FIGURE 4 Plant responses to biocrust presence (weighted mean \pm SE) for the SOIL_REFERENCE_STATE explanatory variable in the five plant response models: (a) overall plant performance, (b) germination, (c) survival, (d) growth, and (e) cover. The number of studies in each moderator group level are shown in parentheses. Lowercase letters denote statistically significant pairwise differences between moderator levels at $p<.05$, and "*" and "+" denote the effect size of a given moderator level is statistically different from zero at $p<.05$ or $0.10>p>.05$ respectively [Colour figure can be viewed at wileyonlinelibrary.com] 


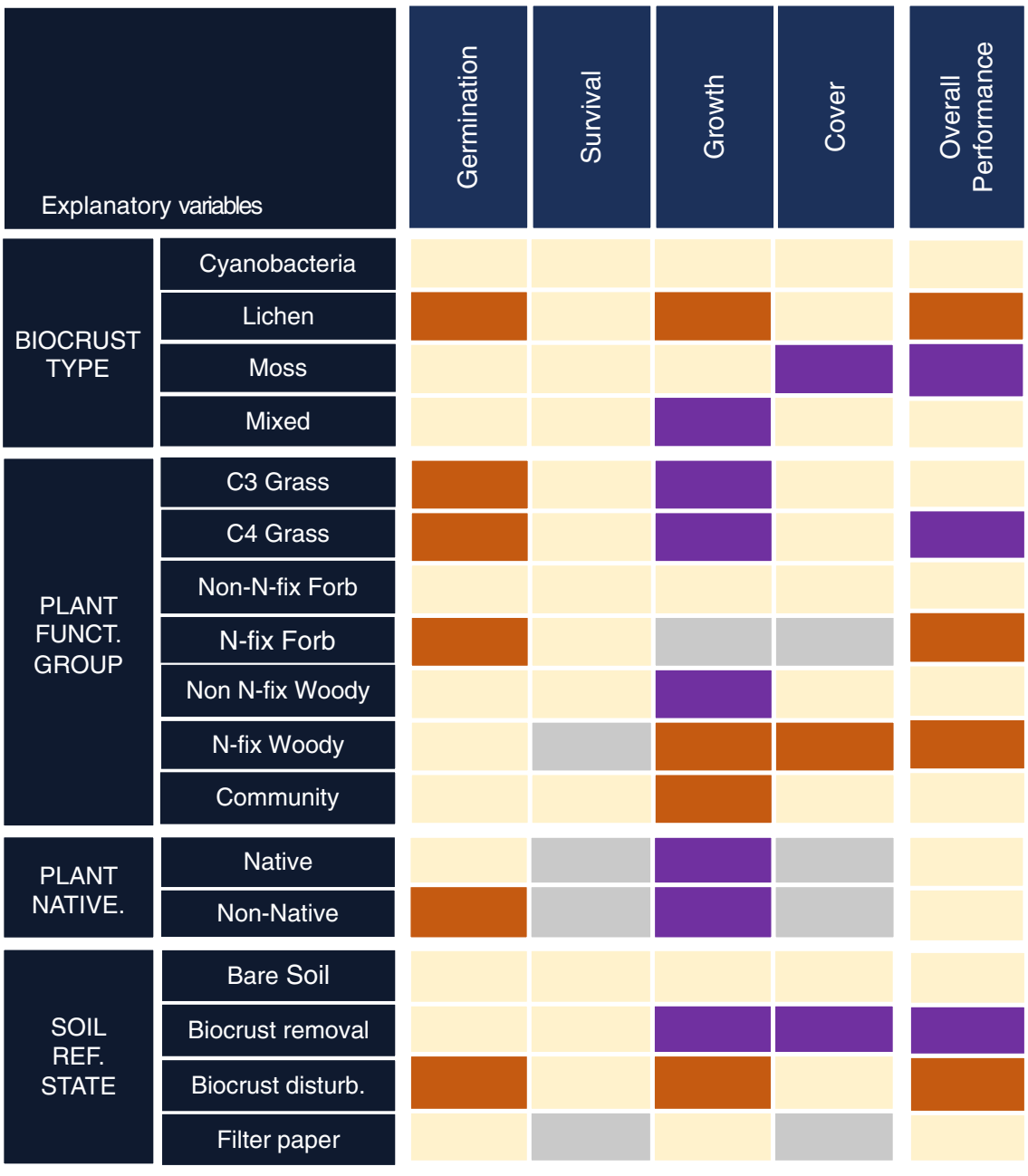

Plant response to biocrust

$\square$ Positive $\square$ Negative $\square$ Neutral $\square$ Not enough

FIGURE 5 Summary diagram showing results for meta-regression of moderators BIOCRUST_TYPE, PLANT_FUNCTIONAL GROUP, PLANT_NATIVENESS, and SOIL_REFERENCE_STATE across the full dataset and (overall performance) and the four individual plant response analysis: germination, survival, growth, and cover. Purple boxes denote positive $(p<.10)$ effects of biocrusts on plant responses and orange boxes denote negative $(p<.10)$ responses. Beige boxes denote no significant effect and grey boxes denote that a given moderator level was not included in the meta-regression model for a given data subset due to insufficient data [Colour figure can be viewed at wileyonlinelibrary.com]

\subsection{2 | Plant functional group}

PLANT_FUNCTIONAL_GROUP was also important for predicting plant responses across all models. Overall plant performance was impacted by plant functional type $(p<.001$; Table 2; Figures 3 and 5 ). $C_{4}$ grass performance was increased $55 \%$ by biocrusts $\left(p<.001\right.$; Figure $3 d$ ), while performance of $C_{3}$ grasses was neutral (Figure 3d). Among non-grasses, non-N-fixing forbs (plants lacking $\mathrm{N}$-fixing symbionts) and woody plants responded neutrally, whereas performance of $\mathrm{N}$-fixing forbs was decreased $23 \%$ in the presence of biocrusts ( $p=.056$; Figure 3). Plant functional type also influenced plant germination responses to biocrusts presence ( $p<.001$; Table 2; Figure $4 \mathrm{~d}$ ). Among grasses, germination of $\mathrm{C}_{4}$ species was decreased 25\% ( $p<.001$; Figure 3 ), while germination of $C_{3}$ species was unaffected by biocrusts (Figure 3 ). Although survival was not significantly different from zero for any functional type, survival among the groups was affected $(p<.001$; Table 2$)$, with survival of $C_{4}$ species greater than any other group (Figure 3). PLANT_FUNCTIONAL_GROUP additionally an important predictor of plant growth ( $p<.001$; Table 2 ). Grasses received the most benefit from biocrust presence, with $C_{4}$ grasses experiencing a $200 \%$ increase ( $p<.001$; Figure 3 ), and $C_{3}$ grasses experiencing a $149 \%$ increase, in growth ( $p<.001$; Figure 3 ) compared to biocrust-absent controls. Growth of non-N-fixing woody plants also increased $56 \%$ with biocrust presence ( $p=.016$; Figure 3 ), while growth of $\mathrm{N}$-fixing woody plants decreased by $38 \%$ ( $p=.010$; Figure 3 ). Biocrust presence decreased the overall growth of plant communities with multiple plant functional types ('Community') by $42 \%$ ( $p=.011$; Figure 3 ). Relationships between biocrusts and plant cover also varied depending on PLANT_FUNCTIONAL_GROUP ( $p<.001$; Table 2, Figure 3). Plant cover responses to biocrusts were only statistically distinct from zero for $\mathrm{N}$-fixing woody plants, which decreased 70\% ( $p=.011$; Figure 3). However, pairwise contrasts between plant functional types revealed among grasses, $C_{4}$ cover was $59 \%$ greater than that 
of $\mathrm{C}_{3}$ species in the presence of biocrusts ( $p<.001$; Figure 3 ). Among non-grasses, cover of non- $\mathrm{N}$-fixing woody plants was approximately one-fold greater than that of $\mathrm{N}$-fixing woody plant species $(p<.001$; Figure 3).

\subsection{3 | Plant nativeness}

PLANT_NATIVENESS was also an important predictor of overall plant performance ( $p=.011$; Table 2 ), although pairwise differences between native and non-native species in the overall dataset were not statistically significant from zero or each other (Figure 3). However, this overall neutral effect was likely driven by opposing native and non-native responses to biocrusts during germination and growth stages of the plant life cycle (Figure 3; Figure 5). Germination was influenced by plant nativeness ( $p<.001$; Table 2 ). The presence of biocrusts reduced germination in non-natives by $10 \%(p=.100$; Figure 3$)$, while native species were unaffected (Figure 4c). In contrast, while plant growth responses to biocrusts were also influenced by PLANT_NATIVENESS $(p<.001$; Table 2; Figure 3 ) the direction of biocrust influences on native and non-native species growth were reversed. Non-native species growth increased $51 \%$ in the presence of biocrust relative to biocrust-absent controls ( $p=.005$; Figure 3 ), whereas the growth of native species was not affected.

\subsection{4 | Soil reference state and other important moderators}

Plant responses to biocrusts were also moderated by the type of uncrusted soil used to compare to biocrusted soils (SOIL_REFERENCE_ STATE; bare soil, biocrust removal, disturbed biocrust, or filter paper; Table 1). SOIL_REFERENCE_STATE influenced overall plant performance responses to biocrust presence $(p<.001$; Table 2; Figures 4 and 5), with overall performance $34 \%$ greater in the presence of biocrusts when compared to biocrust-removed controls ( $p=.024$; Figure 4). Plant germination responses to biocrusts were mediated by soil reference type ( $p=.045$; Table 2; Figure 4) with seedling germination marginally lower on soils with biocrust relative to disturbed biocrust controls ( $-12 \% ; p=.097$; Figure 4). Survival responses also differed by SOIL_REFERENCE_STATE $(p<.001$; Table 2). Mean effect sizes of biocrusts were negative for all control types, though SOIL_REFERENCE_STATE levels were not different from one another (Figure 4). Plant growth responses to biocrusts were influenced by SOIL_REFERENCE_STATE $(p<.001$; Table 2; Figure 4). Among biocrust-absent control surfaces, pairwise contrasts revealed plants benefited most from biocrust presence when compared to biocrust-removed controls $(+190 \% ; p<.001$; Figure 4) while biocrust impacts on plant growth were slightly negative when compared to biocrust disturbance controls $(-27 \% ; p=.094$; Figure 4). Control type also influenced plant cover responses to biocrusts ( $p<.001$; Table 2, Figure 4) with biocrust presence corresponding to a more than two-fold increase in plant cover when compared to biocrust removed controls ( $p<.001$; Figure 4).
Finally, PLANT_DURATION was also an influential explanatory variable in predicting plant survival responses to biocrusts $(p<.001$; Table 2; Figure 3) with survival of perennial plant species on average decreased $54 \%$ by the presence of biocrust ( $p=.061$; Figure 3 ), while biocrust effects on annual species were neutral. To our surprise, neither STUDY_LOCATION nor ECOSYSTEM_OF_ORIGIN, nor their interactions with other moderators were important in any of the plant response models.

\section{4 | DISCUSSION}

Our analysis of 1,004 biocrust-plant studies revealed that there is no simple positive or negative effect of biocrusts on plants (Figures 3-5, Appendix S3). Rather, our results indicate that the overall neutral responses of plants to biocrusts are driven by interspecific variation in plant responses to biocrusts that vary depending on plant and biocrust characteristics and trade-offs in biotic interaction outcomes across different stages of plant ontogeny (i.e. germination, survival, growth, cover). Specifically, our results suggest that biocrusts can act as strong facilitators or competitors of plant species contingent upon biocrust community type, plant functional traits, and disturbance, and suggest areas of future research (Table 3 ) that could increase understanding of the complex relationships between biocrusts and plants.

\section{1 | Biocrusts community composition determines plant responses}

Biocrust community composition was consistently an important explanatory factor for understanding variation in overall plant performance, germination, growth, and cover (Figures 2, 3 and 5). While cyanobacterial biocrusts had few effects on plants at any stage, moss biocrusts increased both overall plant performance and cover, while lichen-dominated biocrusts considerably reduced overall plant performance and germination but lichen-dominated and mixed biocrusts increased plant growth. Potential mechanisms for such contrasts could be differences in water relations and soil fertility driven by differences in biocrust composition. Soil water availability can strongly influence biotic interactions and the structure of plant assemblages in dryland environments (Chesson et al., 2004; Miranda, Armas, Padilla, \& Pugnaire, 2011) and has specifically been shown to mediate biocrust effects on plant community structure (Luzuriaga et al., 2012).

Differences in germination responses to biocrusts may be ascribed to differences in physical structure and water relations among biocrust types. Adequate water availability is first critical to seed water absorption during germination and subsequent seed metabolic activity and radical emergence (Fenner \& Thompson, 2005). Therefore, variability in germination responses among biocrust types can likely be ascribed to differences in community physical structure and impacts on soil water balance. Lichen-dominated biocrust surfaces, especially those with crustose, foliose, or squamulose 
lichens, are often hardened and hydrophobic (Souza-Egipsy, Ascaso, \& Sancho, 2002; Tighe, Haling, Flavel, \& Young, 2012), and can obstruct seed contact with, or penetration into mineral soil (Zhang \& Belnap, 2015), which can expose seeds to drying or predation on the soil surface which may lead to decreased germination (Deines, Rosentreter, Eldridge, \& Serpe, 2007; Schupp, 1995; Serpe, Orm, Barkes, \& Rosentreter, 2006). In contrast, mosses grow in cushions (sometime loosely) and can capture water, including dew and fog (Pan et al., 2016) and thus often promote water infiltration into the soil (Eldridge et al., 2010) and soil water availability (ConcostrinaZubiri et al., 2017). This would enhance water availability to seeds and seedlings, promoting germination, possibly leading to mossdominated biocrusts facilitating plant performance and increasing overall plant cover.

Despite lichen biocrusts having negative effects on some plant life stages, our analysis revealed plant growth generally increased in the presence of lichen and mixed biocrusts. Numerous individual studies have noted the positive effects of lichen-dominated biocrusts on plant biomass when seed penetration and survival filters are overcome (e.g. Langhans, Storm, \& Schwabe, 2009; Pendleton, Pendleton, Howard, \& Warren, 2003). These facilitative effects may result from positive effects on soil moisture and fertility. Biocrusts containing lichens have complex effects on soil hydrology (Chamizo, Belnap, et al., 2016), but can increase soil moisture by reducing runoff (Chamizo, Belnap, et al., 2016) and increasing absorptivity and water holding capacity (Belnap, 2006) which could increase soil water availability to plants. Lichen-dominated and mixed biocrust communities may also increase soil fertility (Barger et al., 2016). Plants grown with lichen and mixed biocrusts have been shown to have greater concentrations of $\mathrm{N}$ and phosphorus in their tissues than plants grown in the absence of these biocrust types (Ferrenberg, Faist, Howell, \& Reed, 2018). Lichens with $\mathrm{N}$-fixing cyanobacterial photobionts (cyanolichens; e.g. Collema) are associated with high levels of $\mathrm{N}$-fixation (Barger et al., 2016; Rosentreter, Eldridge, Westberg, Williams, $\&$ Grube, 2016) and N-fixation may be higher yet in communities containing both cyanolichens and free-living $\mathrm{N}$-fixing cyanobacteria (e.g. Nostoc, Scytonema; Barger et al., 2016).

\section{2 | Plant species traits and nativeness mediate plant responses to biocrusts}

\subsection{1 | Plant functional group: photosynthetic pathway and symbiotic $\mathrm{N}$-fixation influence plant responses to biocrusts}

Plant functional traits, particularly those of beneficiaries of biotic interactions (Soliveres \& Maestre, 2014), often predict the outcome of biotic interactions that may in turn influence community structure (Ackerly \& Cornwell, 2007; Kraft \& Ackerly, 2014; Kraft, Godoy, et al., 2015; Kunstler et al., 2016; Lavorel \& Garnier, 2002; Lebrija-Trejos et al., 2010; McGill et al., 2006). In this study, plant functional type, a proxy for multiple key plant functional traits (i.e. life form, photosynthetic pathway, $\mathrm{N}$-fixation, woodiness), mediated plant response to biocrusts across all models (Table 2, Figure 3). Overall, $C_{4}$ species performance, survival, and cover responses to biocrusts were greater than that of $C_{3}$ species. $C_{3}$ grasses were only positively affected by biocrusts during growth (Figure 3 ). In contrast, $C_{4}$ species, despite a significant decrease in germination, showed an increase in both overall performance and growth by biocrusts. This pattern is similar to studies that have shown $\mathrm{C}_{4}$ species receive greater benefits than $\mathrm{C}_{3}$ species from the presence of soil microorganisms such as arbuscular mycorrhizal fungi (e.g. Hetrick, Wilson, \& Todd, 1990; Hoeksema et al., 2010). Overall, our results conflict with our predictions for $C_{3}$ and $C_{4}$ grasses. $C_{3}$ species have lower water- and $\mathrm{N}$-use efficiency compared to $C_{4}$ species (Pearcy \& Ehleringer, 1984). Thus, we would expect $C_{3}$ species overall would receive greater benefits from biocrusts, which presumably increase soil water and nutrient availability relative to uncrusted soil. One potential explanation for this pattern is that biocrusts that contain darkly pigmented cyanobacteria (e.g. Nostoc, Scytonema, Tolypothrix) are often associated with elevated soil surface temperature (Couradeau et al., 2016), $C_{4}$ species may respond more favorably to biocrusts given their greater temperature requirements and tolerances compared to $C_{3}$ species (Pearcy \& Ehleringer, 1984; Sage \& Kubien, 2007).

Among non-grasses, plants species lacking bacterial $\mathrm{N}$-fixing symbionts exhibited a more positive response to biocrusts than $\mathrm{N}$ fixing species (Figure 3). This result suggests the benefits of $\mathrm{N}$-fixing symbionts to plants are precluded in the presence of $\mathrm{N}$-fixing biocrusts. Empirical evidence suggests that when soil nutrient limitations are relaxed, net benefits of maintaining $\mathrm{N}$-fixing symbionts are decreased and may in turn lead to decreased performance of $\mathrm{N}$-fixing plant species (Suding et al., 2005; Vitousek, Menge, Reed, \& Cleveland, 2013). This pattern was less defined in survival, growth, and cover analyses, perhaps due to relatively low sample size of $\mathrm{N}$ fixing forbs and woody plant species in these analyses, indicating additional studies are needed that directly compare the responses of plant species with and without $\mathrm{N}$-fixing symbionts.

\subsubsection{Plant nativeness: Biocrust influences on native versus non-native plants shift across plant ontogeny}

We might expect that biocrusts, acting as strong facilitators or inhibitors would similarly influence both native and non-native plant species performance in the case of similar traits among native and non-native species. However, since the native plant community has likely coevolved in the presence of biocrusts and may have already experienced historical and ongoing facilitation or filtering, we might expect a divergence in traits of exotics and native plants and a differential response to biocrusts.

Overall, biocrusts inhibited the germination of non-native species. This negative effect is consistent with past reports that biocrusts pose greater inhibition to non-native versus native seeds (Deines et al., 2007; Hernandez \& Sandquist, 2011; Song, Li, \& Hui, 2017) and may be partially explained by physical interactions between nonnative seed morphological traits and biocrusts. Nearly half $(48.6 \%)$ 
TAB LE 3 Identified knowledge gaps and future research needs

\begin{tabular}{|c|c|}
\hline Knowledge gap or needed research & Description \\
\hline $\begin{array}{l}\text { Biocrust impacts on plant commu- } \\
\text { nity assembly and diversity }\end{array}$ & $\begin{array}{l}\text { Direct tests of hypotheses pertaining to biocrust mediation of plant community assembly and diversity } \\
\text { patterns at multiple spatial scales are needed. }\end{array}$ \\
\hline Studies across the plant lifecycle & $\begin{array}{l}\text { Given observed variability in plant responses to biocrusts depending on plant life stage, future studies } \\
\text { should track plant responses to biocrusts across the entire plant lifecycle. Additionally, biocrust effects } \\
\text { on plant phenology and sexual reproduction should be examined. }\end{array}$ \\
\hline Trait-based approaches & $\begin{array}{l}\text { Explicit tests of the interactions between specific plant functional traits, life forms, and strategies and } \\
\text { biocrusts are needed. For example: } \\
\text { - } \mathrm{C}_{3} \text { versus } \mathrm{C}_{4} \text { grasses; } \\
\text { - Presence and absence of } \mathrm{N} \text {-fixing symbionts; } \\
\text { - Bunchgrasses versus rhizomatous species; } \\
\text { - Annuals versus perennials. } \\
\text { In addition, obtaining a greater understanding of how seed characteristics influence plant establishment is } \\
\text { critical. }\end{array}$ \\
\hline $\begin{array}{l}\text { Mechanisms underlying plant } \\
\text { responses to biocrusts }\end{array}$ & $\begin{array}{l}\text { Future work should directly examine mechanisms whereby biocrusts drive plant species and community } \\
\text { responses to biocrusts (e.g. water relations, nutrient cycling, fungal networks). }\end{array}$ \\
\hline Geographic inclusivity & $\begin{array}{l}\text { There is need for additional study of plant responses to biocrusts in South America, Australia, and Africa. } \\
\text { Moreover, studies of plant responses to biocrusts in arctic and alpine ecosystems are needed. }\end{array}$ \\
\hline $\begin{array}{l}\text { Climatic gradient studies and cli- } \\
\text { mate manipulation experiments }\end{array}$ & $\begin{array}{l}\text { Variation in climate likely plays important roles in determining plant responses to biocrusts. Future re- } \\
\text { search should provide detailed climatic data for study sites and address how biocrust-plant interactions } \\
\text { may shift across existing climatic gradients. } \\
\text { Climate change will impact the dynamics and structure of biocrust and plant communities. Future work } \\
\text { should explore how plant responses to biocrusts may change in a global change context and examine } \\
\text { potential feedbacks between biocrust-plant interactions and climate change. }\end{array}$ \\
\hline Consistent experimental protocols & $\begin{array}{l}\text { Finally, we call for a common set of protocols to be adopted by researchers studying this topic to facilitate } \\
\text { better comparisons among results. For example, we suggest studies should include: } \\
\text { - Biocrust-absent controls and their descriptions } \\
\text { - Detailed descriptions of biocrust community composition (e.g. functional group dominance, cover) } \\
\text { - Soil texture information } \\
\text { - Soil moisture data and experimental watering treatment information } \\
\text { - Soil nutrient data }\end{array}$ \\
\hline
\end{tabular}

of germination studies included in our database addressed biocrust effects on non-native grasses with seeds with large awns (e.g. Bromus, Schismus spp.). Large awns may decrease or prevent contact between the seed and the mineral soil surface and can prevent the seeds from slipping into small cracks found in the biocrusts leaving seeds on the soil surface vulnerable to predation and lacking sufficient moisture to germinate (Belnap, Phillips, \& Troxler, 2006; Deines et al., 2007; Morgan, 2006; Zhang \& Belnap, 2015). Seed size may also govern plant germination responses to biocrusts. For instance, a study conducted by Morgan (2006) in grasslands of southwestern Australia found the large-seeded non-native grass species Briza maxima showed stronger inhibition by biocrusts than smaller seeded native species. Together, these morphological mechanisms are thought to play an important role in biocrust suppression of germination in awned, large-seeded Bromus species in the western US (Evans \& Young, 1984; Hernandez \& Sandquist, 2011; Howell, 1998; Peterson, 2013; Reisner et al., 2013) and Israel (Prasse \& Bornkamm, 2000), Salsola species in Australia and the US (West, 1990), and Schismus species in Australia and Israel (Crisp, 1975; Zaady et al., 1997).

In contrast to germination responses, non-native plant species growth increased on average two-fold by biocrusts (Figure 3 ), indicating potential tradeoffs in non-native plant responses to biocrusts across plant ontogeny. This result is supported by individual studies that have reported increased growth in non-native and invasive plants by biocrusts (Defalco et al., 2001; Ferrenberg et al., 2018; Pendleton et al., 2003). Most existing studies compare responses of exotic annuals to native perennial plants. As annual plants often have greater relative fitness than native perennials when key resources are not limiting, as often found in biocrusted soils, these results are not surprising (Davis, Grime, \& Thompson, 2000; Van Kleunen, Weber, $\&$ Fischer, 2010). These results also suggest intact biocrust communities can act as a barrier exotic grass species invasion by inhibiting germination. However, once established, the exotic annuals may be more able than the native perennials to utilize the resources available in biocrusted soils leading to heightened competitive ability.

\subsection{Soil disturbance mediates biocrust impacts on plant performance}

Perhaps the best approach for understanding the importance of biotic interactions in filtering or facilitating plant species is to remove a putative influence and observe the effects. This approach 
to understanding biocrust-plant interactions exists in studies with two common methodologies: those where biocrusts have been removed (e.g. scraping away the biocrust layer) and those where biocrusts have been disturbed (e.g. trampling biocrusted surfaces). Both approaches suggest important interactions among plants and biocrusts, but we found that the method of eliminating the biocrust had an important influence on outcomes (Table 2; Figures 4 and 5). In studies where biocrusts were removed, biocrusts had positive effects on overall plant performance, whereas biocrusts had a slightly negative effect on plant performance relative to plots where biocrusts were disturbed but not removed. This effect was mainly driven by plant growth but was also supported by patterns in germination and cover. These results suggest that upon mechanical disturbance of biocrusts, there may be initial increases in plant performance, indicating potential competition between intact biocrusts and plant communities. Individual studies have shown biocrust disturbance can increase the survival and growth of seedlings (Hernandez \& Sandquist, 2011; Langhans, Storm, \& Schwabe, 2010; Li et al., 2012), potentially because of temporary nutrient pulses released from biocrusts during biocrust disturbance (Beyschlag, Wittland, Jentsch, \& Steinlein, 2008) and decomposition (Maestre et al., 2013), altered water infiltration rates via disruption of physical crusting or hydrophobic biocrust organisms (Chamizo, Belnap, et al., 2016; Chamizo, Cantón, Lázaro, SoléBenet, \& Domingo, 2012) or enhancing seed burial. Yet, our results suggest that if disturbances persist, resulting in complete biocrust removal, such positive effects may decrease.

\section{4 | Biocrusts: biotic filters and facilitators for plant community assemblages?}

Biotic interactions can strongly influence plant community assembly outcomes (Boulangeat et al., 2012; HilleRisLambers et al., 2012; Levine et al., 2004; Lortie et al., 2004). Collectively, results from this meta-analysis suggest strong context-dependency in plant responses to biocrusts. Given the potential of biocrusts to have positive, neutral, or negative effects on plant species performance, it is likely that biocrusts influence plant community assembly and composition by promoting the performance of certain plant species while inhibiting others. As a working hypothesis to be tested further, we advance a few provisional generalizations summarizing the potential role of biocrusts in plant community assembly:

1. Different biocrusts types differentially facilitate or inhibit potential plant community members. Specifically, biocrust community composition can determine whether biocrusts facilitate, inhibit, or neutrally affect plant species. For example, moss-dominated biocrusts positively influenced plant performance overall, while lichen-dominated biocrusts negatively impacted plant performance.

2. Plant traits may be diminished or enhanced in the presence of biocrusts. Effects of biocrusts on plants are not uniformly experienced by all members of the plant community. Specifically, $C_{4}$ grasses responded more positively to biocrusts than $C_{3}$ grasses and $\mathrm{N}$-fixing species were more negatively affected by biocrusts than non-N-fixing species.

3. The effect of biocrusts on plants shifts across plant ontogeny and may suggest trait-based tradeoffs that may equalize overall performance of functionally diverse competitors. Biocrusts reduce germination in non-native plants and $\mathrm{C}_{4}$ grasses but subsequently benefit these two groups in later life stages. Such trade-offs in interaction outcomes across plant ontogeny could be a mechanism that allows inferior competitors to coexist with these two groups which otherwise have adaptations that help to buffer them against environmental fluctuations.

4. Biocrusts can facilitate or inhibit potential plant community members, depending on the disturbance level. Our results suggest that, compared to a simulated highly disturbed environment, biocrusts are likely to exert a positive influence on potential plant community members, although the magnitude is contingent on biocrust type and plant traits. This observation aligns with ecological hypotheses that increased disturbance and/or abiotic stress may increase the importance of niche-based processes once stochastic influences of species dispersal dissipate (e.g. Ferrenberg et al., 2013; Jiang \& Patel, 2008) and competition and facilitation between interacting species begins structuring communities (Bruno et al., 2003; Gross et al., 2010; Liancourt et al., 2005).

Biotic interactions are increasingly being incorporated into plant community theory (Bruno et al., 2003; Lortie et al., 2004; Maestre, Callaway, Valladares, \& Lortie, 2009) and predictions into how communities will respond to accelerating environmental change (Brooker et al., 2008; He et al., 2013; McCluney et al., 2012; Van der Putten et al., 2010). Given the acute vulnerability of biocrusts to ongoing and future climate change and land-use intensification (Ferrenberg et al., 2015; Reed et al., 2012; Rodriguez-Caballero et al., 2018), understanding biocrust contributions to plant community assembly and structure may be particularly important for predicting how communities will respond to global change. We show biocrusts can have strong, context-dependent effects on plant species. Therefore, we suggest their integration in the development of plant community theory is needed, in a manner akin to ongoing efforts to understand the broader influences of soil microbial communities on vegetation community structure (Bever et al., 2010; Kardol, Cornips, Van Kempen, Bakx-Schotman, \& Van Der Putten, 2007; Van Der Heijden et al., 2008).

\section{ACKNOWLEDGEMENTS}

This work was conducted as part of the 'Completing the dryland puzzle: creating a predictive framework for biological soil crust function and response to climate change' Working Group supported by the John Wesley Powell Center for Analysis and Synthesis, funded by the U.S. Geological Survey. We thank the University of Colorado Boulder Undergraduate Research Opportunities Program (UROP), which helped support undergraduate researchers who assisted with data entry for this project. Particularly, we thank CU Boulder undergraduate researcher assistants Emma Brokyl, Julius Gayo 
and Whitney Gabbert for their invaluable work on database compilation and organization for this project. C.A.H. was supported by the Department of Ecology and Evolutionary Biology at the University of Colorado Boulder and a National Science Foundation Graduate Research Fellowship (award DGE-1144083). V.B.C. was supported by grants from the National Science Foundation (award DEB-1844531) and the DePaul University College of Science and Health. E.H.S. was supported by Consejo Nacional de Ciencia y Tecnología (project SEP-CONACYT 251388). J.B. was supported by the USGS Ecosystem and Land Change Sciences program. Any use of trade, firm or product names is for descriptive purposes only and does not imply endorsement by the U.S. Government.

\section{AUTHORS' CONTRIBUTIONS}

C.A.H. compiled and formatted the database, performed data analysis, designed figures wrote the first draft of the manuscript. V.B.C., S.F., A.J.A., J.B., M.A.B., D.J.E., A.M.F., E.H.-S., A.D.L., E.R.-C., Y.Z. and N.N.B. contributed to editing the manuscript. A.J.A., N.N.B., J.B. and M.A.B. are co-PIs on the grant that supported this work and helped with project logistics and organization. Y.Z. performed literature search and database compilation for all Chinese literature included in the database. A.D.L. assisted with literature searches, database compilation, formatting and troubleshooting. V.B.C. consulted on the structure of the database, participated in data validation and quality control, provided code and contributed to the methodological approach to data analysis.

\section{DATA AVAILABILITY STATEMENT}

The database compiled and used in this meta-analysis (BSC-PLANT Database) is available from the Dryad Digital Repository: https://doi. org/10.5061/dryad.sr83ph7 (Havrilla et al., 2019).

\section{ORCID}

Caroline A. Havrilla (iD https://orcid.org/0000-0003-3913-0980 Scott Ferrenberg (iD https://orcid.org/0000-0002-3542-0334 Anita J. Antoninka iD https://orcid.org/0000-0001-6583-9892 Jayne Belnap (iD https://orcid.org/0000-0001-7471-2279 Matthew A. Bowker iD https://orcid.org/0000-0002-5891-0264 David J. Eldridge (iD https://orcid.org/0000-0002-2191-486X Akasha M. Faist (iD https://orcid.org/0000-0003-3553-2739 Elisabeth Huber-Sannwald iD https://orcid.org/0000-0002-8321-1270 Emilio Rodriguez-Caballero (iD https://orcid.org/0000-0002-5934-3214 Nichole N. Barger (iD https://orcid.org/0000-0002-8765-7974

\section{REFERENCES}

Ackerly, D. D., \& Cornwell, W. K. (2007). A trait-based approach to community assembly: partitioning of species trait values into within-and among-community components. Ecology letters, 10(2), 135-145. https://doi.org/10.1111/j.1461-0248.2006.01006.x

Barger, N. N., Weber, B., Garcia-Pichel, F., Zaady, E., \& Belnap, J. (2016). Patterns and controls on nitrogen cycling of biological soil crusts. In B. Webber, B. Büdel, \& J. Belnap (Eds.), Biological soil crusts: An organizing principle in drylands (pp. 257-285). Cham, Switzerland: Springer. https://doi.org/10.1007/978-3-319-30214-0_14

Belnap, J. (2006). The potential roles of biological soil crusts in dryland hydrologic cycles. Hydrological Processes, 20(15), 3159-3178. https:// doi.org/10.1002/hyp.6325

Belnap, J., \& Büdel, B. (2016). Biological soil crusts as soil stabilizers. In B. Webber, B. Büdel, \& J. Belnap (Eds.), Biological soil crusts: An organizing principle in drylands (pp. 305-320). Cham, Switzerland: Springer.

Belnap, J., \& Harper, K. T. (1995). Influence of cryptobiotic soil crusts on elemental content of tissue of two desert seed plants. Arid Land Research and Management, 9(2), 107-115. https://doi. org/10.1080/15324989509385879

Belnap, J., Phillips, S. L., \& Troxler, T. (2006). Soil lichen and moss cover and species richness can be highly dynamic: The effects of invasion by the annual exotic grass Bromus tectorum, precipitation, and temperature on biological soil crusts in SE Utah. Applied Soil Ecology, 32(1), 63-76. https://doi.org/10.1016/j.apsoil.2004.12.010

Belnap, J., Prasse, R., \& Harper, K. T. (2003). Influence of biological soil crusts on soil environments and vascular plants. In J. Belnap \& O. L. Lange (Eds.), Biological soil crusts: Structure, function, and management (2nd edn, pp. 281-300). Berlin, Heidelberg: Springer. https://doi. org/10.1007/978-3-642-56475-8_21

Belnap, J., Weber, B., \& Büdel, B. (2016). Biological soil crusts as an organizing principle in drylands. In B. Weber, B. Büdel, \& J. Belnap (Eds.), Biological soil crusts: An organizing principle in drylands. Ecological Studies (Analysis and Synthesis) (Vol. 226, pp. 3-13). Cham, Switzerland: Springer.

Beraldi-Campesi, H. (2013). Early life on land and the first terrestrial ecosystems. Ecological Processes, 2(1), 1. https://doi. org/10.1186/2192-1709-2-1

Bever, J. D., Dickie, I. A., Facelli, E., Facelli, J. M., Klironomos, J., Moora, M., ... Zobel, M. (2010). Rooting theories of plant community ecology in microbial interactions. Trends in Ecology and Evolution, 25(8), 468-478. https://doi.org/10.1016/j.tree.2010.05.004

Beyschlag, W., Wittland, M., Jentsch, A., \& Steinlein, T. (2008). Soil crusts and disturbance benefit plant germination, establishment and growth on nutrient deficient sand. Basic and applied ecology, 9(3), 243-252. https://doi.org/10.1016/j.baae.2007.03.002

Boulangeat, I., Gravel, D., \& Thuiller, W. (2012). Accounting for dispersal and biotic interactions to disentangle the drivers of species distributions and their abundances. Ecology Letters, 15(6), 584-593. https:// doi.org/10.1111/j.1461-0248.2012.01772.x

Bowker, M. A., Belnap, J., Chaudhary, V. B., \& Johnson, N. C. (2008). Revisiting classic water erosion models in drylands: The strong impact of biological soil crusts. Soil Biology and Biogeochemistry, 40(9), 2309-2316. https://doi.org/10.1016/j.soilbio.2008.05.008

Bowker, M. A., Mau, R. L., Maestre, F. T., Escolar, C., \& Castillo-Monroy, A. P. (2011). Functional profiles reveal unique ecological roles of various biological soil crust organisms. Functional Ecology, 25(4), 787795. https://doi.org/10.1111/j.1365-2435.2011.01835.x

Breen, K., \& Levesque, E. (2006). Proglacial succession of biological soil crusts and vascular plants: Biotic interactions in the High Arctic. Canadian Journal of Botany, 84(11), 1714-1731. https://doi. org/10.1139/b06-131

Briggs, A. L., \& Morgan, J. W. (2011). Seed characteristics and soil surface patch type interact to affect germination of semi-arid woodland species. Plant Ecology, 212(1), 91-103. https://doi.org/10.1007/ s11258-010-9806-x

Brooker, R. W., Maestre, F. T., Callaway, R. M., Lortie, C. L., Cavieres, L. A., Kunstler, G., ... Michalet, R. (2008). Facilitation in plant communities: 
The past, the present, and the future. Journal of Ecology, 96(1), 18-34. https://doi.org/10.1111/j.1365-2745.2007.01295.x

Bruno, J. F., Stachowicz, J. J., \& Bertness, M. D. (2003). Inclusion of facilitation in to ecological theory. Trends in Ecology and Evolution, 18, 119-125. https://doi.org/10.1016/S0169-5347(02)00045-9

Callaway, R. M. (2007). Positive interactions and interdependence in plant communities. Dordrecht: Springer.

Chamizo, S., Belnap, J., Eldridge, D. J., Cantón, Y., \& Issa, O. M. (2016). The role of biocrusts in arid land hydrology. In B. Webber, B. Büdel, \& J. Belnap (Eds.), Biological soil crusts: An organizing principle in drylands (pp. 321-346). Cham: Springer.

Chamizo, S., Cantón, Y., Lázaro, R., Solé-Benet, A., \& Domingo, F. (2012). Crust composition and disturbance drive infiltration through biological soil crusts in semiarid ecosystems. Ecosystems, 15(1), 148-161. https://doi.org/10.1007/s10021-011-9499-6

Chamizo, S., Cantón, Y., Miralles, I., \& Domingo, F. (2012). Biological soil crust development affects physicochemical characteristics of soil surface in semiarid ecosystems. Soil Biology and Biochemistry, 49, 96-105. https://doi.org/10.1016/j.soilbio.2012.02.017

Chesson, P., Gebauer, R. L. E., Schwinning, S., Huntly, N., Wiegand, K., Ernest, M. S. K., ... Weltzin, J. F. (2004). Resource pulses, species interactions, and diversity maintenance in arid and semi-arid environments. Oecologia, 141(2), 236-253. https://doi.org/10.1007/ s00442-004-1551-1

Chung, Y. A., \& Rudgers, J. A. (2016). Plant-soil feedbacks promote negative frequency dependence in the coexistence of two aridland grasses. Proceedings of The. Royal Society B, 283(1835), 20160608. https://doi.org/10.1098/rspb.2016.0608

Concostrina-Zubiri, L., Huber-Sannwald, E., Martínez, I., Flores, J. F., \& Escudero, A. (2013). Biological soil crusts greatly contribute to small-scale soil heterogeneity along a grazing gradient. Soil Biology and Biochemistry, 64, 28-36. https://doi.org/10.1016/j.soilb io.2013.03.029

Concostrina-Zubiri, L., Molla, I., Velizarova, E., \& Branquinho, C. (2017). Grazing or not grazing: Implications for ecosystem services provided by biocrusts in Mediterranean cork oak woodlands. Land Degradation and Development, 28(4), 1345-1353. https://doi.org/10.1002/ldr.2573

Cornwell, W. K., \& Ackerly, D. D. (2009). Community assembly and shifts in plant trait distributions across an environmental gradient in coastal California. Ecological Monographs, 79(1), 109-126. https://doi. org/10.1890/07-1134.1

Couradeau, E., Karaoz, U., Lim, H. C., Da Rocha, U. N., Northen, T., Brodie, E., \& Garcia-Pichel, F. (2016). Bacteria increase arid-land soil surface temperature through the production of sunscreens. Nature Communications, 7, 10373. https://doi.org/10.1038/ncomms10373

Crisp, M. D. (1975). Long-term change in arid zone vegetation. Unpublished Thesis. PhD University of Adelaide, Australia. Retrieved from http://hdl.handle.net/2440/20725

Davis, M. A., Grime, J. P., \& Thompson, K. (2000). Fluctuating resources in plant communities: A general theory of invasibility. Journal of Ecology, 88(3), 528-534. https://doi.org/10.1046/j.1365-2745.2000.00473.x

De'Ath, G. (2007). Boosted trees for ecological modeling and prediction. Ecology, 88(1), 243-251. https://doi.org/10.1890/0012-9658(2007)8 8[243:BTFEMA]2.0.CO;2

DeFalco, L. A., Detling, J. K., Tracy, C. R., \& Warren, S. D. (2001). Physiological variation among native and exotic winter annual plants associated with microbiotic crusts in the Mojave Desert. Plant and Soil, 234(1), 1-14. https://doi.org/10.1023/A:1010323001006

Deines, L., Rosentreter, R., Eldridge, D. J., \& Serpe, M. D. (2007). Germination and seedling establishment of two annual grasses on lichen-dominated biological soil crusts. Plant and Soil, 295(1-2), 23-35. https://doi.org/10.1007/s11104-007-9256-y

Eldridge, D. J., Bowker, M. A., Maestre, F. T., Alonso, P., Mau, R. L., Papadopoulos, J., \& Escudero, A. (2010). Interactive effects of three ecosystem engineers on infiltration in a semi-arid Mediterranean grassland. Ecosystems, 13(4), 499-510. https://doi.org/10.1007/ s10021-010-9335-4

Eldridge, D. J., Semple, W. S., \& Koen, T. B. (2000). Dynamics of cryptogamic soil crusts in a derived grassland in south-eastern Australia. Austral Ecology, 25(3), 232-240. https://doi. org/10.1046/j.1442-9993.2000.01023.x

Elith, J., \& Leathwick, J. (2017). Boosted Regression Trees for ecological modeling. R documentation. https://cran.r-project.org/web/packa ges/dismo/vignettes/brt.pdf

Elith, J., Leathwick, J. R., \& Hastie, T. (2008). A working guide to boosted regression trees. Journal of Animal Ecology, 77(4), 802-813. https:// doi.org/10.1111/j.1365-2656.2008.01390.x

Evans, R. A., \& Young, J. A. (1984). Microsite requirements for downy brome (Bromus tectorum) infestation and control on sagebrush rangelands. Weed Science, 32, 13-17. https://doi.org/10.1017/S0043 174500060197

Faist, A. M., Herrick, J. E., Belnap, J., Van Zee, J. W., \& Barger, N. N. (2017). Biological soil crust and disturbance controls on surface hydrology in a semi-arid ecosystem. Ecosphere, 8(3), https://doi.org/10.1002/ ecs2.1691

Fenner, M., \& Thompson, K. (2005). The ecology of seeds. Cambridge, UK: Cambridge University Press.

Ferrenberg, S., Faist, A. M., Howell, A., \& Reed, S. C. (2018). Biocrusts enhance soil fertility and Bromus tectorum growth, and interact with warming to influence germination. Plant and Soil, 1-14, https://doi. org/10.1007/s11104-017-3525-1

Ferrenberg, S., O'Neill, S. P., Knelman, J. E., Todd, B., Duggan, S., Bradley, D., ... Nemergut, D. R. (2013). Changes in assembly processes in soil bacterial communities following a wildfire disturbance. The ISME Journal, 7(6), 1102. https://doi.org/10.1038/ ismej.2013.11

Ferrenberg, S., Reed, S. C., \& Belnap, J. (2015). Climate change and physical disturbance cause similar community shifts in biological soil crusts. Proceedings of the National Academy of Sciences of the United States of America, 112(39), 12116-12121. https://doi.org/10.1073/ pnas.1509150112

Fox, J., \& Weisberg, S. (2011). An R companion to applied regression (2nd ed.). Thousand Oaks, CA: Sage. Retrieved from http://socserv.socsci. mcmaster.ca/jfox/Books/Companion.

Friedman, J. H., \& Meulman, J. J. (2003). Multiple additive regression trees with application in epidemiology. Statistics in Medicine, 22(9), 1365-1381. https://doi.org/10.1002/sim.1501

Gelbard, J. L., \& Belnap, J. (2003). Roads as conduits for exotic plant invasions in a semiarid landscape. Conservation Biology, 17(2), 420-432. https://doi.org/10.1046/j.1523-1739.2003.01408.x

Godínez-Alvarez, H., Morín, C., \& Rivera-Aguilar, V. (2012). Germination, survival and growth of three vascular plants on biological soil crusts from a Mexican tropical desert. Plant Biology, 14(1), 157-162. https:// doi.org/10.1111/j.1438-8677.2011.00495.x

Gross, N., Liancourt, P., Choler, P., Suding, K. N., \& Lavorel, S. (2010). Strain and vegetation effects on local limiting resources explain the outcomes of biotic interactions. Perspectives in Plant Ecology, Evolution, and Systematics, 12, 9-49. https://doi.org/10.1016/j. ppees.2009.09.001

Guo, Y., Zhao, H., Zuo, X., Drake, S., \& Zhao, X. (2008). Biological soil crust development and its topsoil properties in the process of dune stabilization, Inner Mongolia, China. Environmental Geology, 54(3), 653-662. https://doi.org/10.1007/s00254-007-1130-y

Havrilla, C. A., \& Barger, N. N. (2018). Biocrusts and their disturbance mediate the recruitment of native and exotic grasses from a hot desert ecosystem. Ecosphere, 9(7), e02361. https://doi.org/10.1002/ ecs2.2361

Havrilla, C. A., Chaudhary, V. B., Ferrenberg, S., Antoninka, A. J., Belnap, J., Bowker, M. A., ... Barger, N. N. (2019). Data from: Towards a predictive framework for biocrust mediation of plant performance: $A$ 
meta-analysis. Dryad Digital Repository, https://doi.org/10.5061/ dryad.sr83ph7

He, Q., Bertness, M. D., \& Altieri, A. H. (2013). Global shifts towards positive species interactions with increasing environmental stress. Ecology Letters, 16(5), 695-706. https://doi.org/10.1111/ele.12080

Hedges, L. V., Gurevitch, J., \& Curtis, P. S. (1999). The meta-analysis of response ratios in experimental ecology. Ecology, 80, 1150-1156. https ://doi.org/10.1890/0012-9658(1999)080[1150:TMAORR]2.0.CO;2

Hernandez, R. R., \& Sandquist, D. R. (2011). Disturbance of biological soil crust increases emergence of exotic vascular plants in California sage scrub. Plant Ecology, 212(10), 1709. https://doi.org/10.1007/ s11258-011-9943-x

Hetrick, B. A. D., Wilson, G. W. T., \& Todd, T. C. (1990). Differential responses of $\mathrm{C} 3$ and $\mathrm{C} 4$ grasses to mycorrhizal symbiosis, phosphorus fertilization, and soil microorganisms. Canadian Journal of Botany, 68(3), 461-467. https://doi.org/10.1139/b90-061

Hijmans, R. J., Phillips, S., Leathwick, J., Elith, J., \& Hijmans, M. R. J. (2017). Package 'dismo'. Circles, 9(1).

HilleRisLambers, J., Adler, P. B., Harpole, W. S., Levine, J. M., \& Mayfield, M. M. (2012). Rethinking community assembly through the lens of coexistence theory. Annual Review of Ecology, Evolution, and Systematics, 43, 227-248. https://doi.org/10.1146/annurev-ecolsys-110411-160411

Hoeksema, J. D., Chaudhary, V. B., Gehring, C. A., Johnson, N. C., Karst, J., Koide, R. T., ... Umbanhowar, J. (2010). A meta-analysis of context-dependency in plant response to inoculation with mycorrhizal fungi. Ecology Letters, 13(3), 394-407. https://doi. org/10.1111/j.1461-0248.2009.01430.x

Hortal, S., Lozano, Y. M., Bastida, F., Armas, C., Moreno, J. L., Garcia, C., \& Pugnaire, F. I. (2017). Plant-plant competition outcomes are modulated by plant effects on the soil bacterial community. Scientific Reports, 7(1), 17756. https://doi.org/10.1038/s41598-017-18103-5

Howell, W. (1998). Germination and establishment of Bromus tectorum L. in relation to cation exchange capacity, seedbed, litter, soil cover and water. Unpublished Thesis, Prescott College, AZ

Jafari, M., Tavili, A., Zargham, N., Heshmati, G. A., Chahouki, M. Z., Shirzadian, S....Sohrabi, M. (2004). Comparing some properties of crusted and uncrusted soils in Alagol Region of Iran. Pakistan Journal of Nutrition, 3(5), 273-277. https://doi.org/10.3923/ pjn.2004.273.277

Jiang, L., \& Patel, S. N. (2008). Community assembly in the presence of disturbance: A microcosm experiment. Ecology, 89, 1931-1940. https ://doi.org/10.1890/07-1263.1

Kardol, P., Cornips, N. J., van Kempen, M. M., Bakx-Schotman, J. M., \& van der Putten, W. H. (2007). Microbe-mediated plant-soil feedback causes historical contingency effects in plant community assembly. Ecological Monographs, 77(2), 147-162. https://doi. org/10.1890/06-0502

Keddy, P. A. (1992). Assembly and response rules: Two goals for predictive community ecology. Journal of Vegetation Science, 3(2), 157-164. https://doi.org/10.2307/3235676

Kenrick, P., \& Crane, P. R. (1997). The origin and early evolution of plants on land. Nature, 389(6646), 33. https://doi.org/10.1038/37918

Kraft, N. J., \& Ackerly, D. D. (2014). Assembly of plant communities. In R. K. Monson (ed.), Ecology and the environment (pp. 67-88). New York, NY: Springer.

Kraft, N. J., Adler, P. B., Godoy, O., James, E. C., Fuller, S., \& Levine, J. M. (2015). Community assembly, coexistence and the environmental filtering metaphor. Functional Ecology, 29(5), 592-599. https://doi. org/10.1111/1365-2435.12345

Kraft, N. J., Godoy, O., \& Levine, J. M. (2015). Plant functional traits and the multidimensional nature of species coexistence. Proceedings of the National Academy of Sciences of the United States of America, 112(3), 797-802. https://doi.org/10.1073/pnas.1413650112

Kunstler, G., Falster, D., Coomes, D. A., Hui, F., Kooyman, R. M., Laughlin, D. C., ... Westoby, M. (2016). Plant functional traits have globally consistent effects on competition. Nature, 529(7585), 204. https:// doi.org/10.1038/nature16476

Lan, S., Wu, L., Zhang, D., \& Hu, C. (2013). Assessing level of development and successional stages in biological soil crusts with biological indicators. Microbial Ecology, 66(2), 394-403. https://doi.org/10.1016/j. apsoil.2016.11.009

Langhans, T. M., Storm, C., \& Schwabe, A. (2009). Biological soil crusts and their microenvironment: Impact on emergence, survival and establishment of seedlings. Flora-Morphology, Distribution, Functional Ecology of Plants, 204(2), 157-168. https://doi.org/10.1016/j. flora.2008.01.001

Langhans, T. M., Storm, C., \& Schwabe, A. (2010). Regeneration processes of biological soil crusts, macro-cryptogams and vascular plant species after fine-scale disturbance in a temperate region: Recolonization or successional replacement? Flora-Morphology, Distribution, Functional Ecology of Plants, 205(1), 46-60. https://doi. org/10.1016/j.flora.2008.12.001

Lavorel, S., \& Garnier, É. (2002). Predicting changes in community composition and ecosystem functioning from plant traits: Revisiting the Holy Grail. Functional Ecology, 16(5), 545-556. https://doi. org/10.1046/j.1365-2435.2002.00664.x

Lebrija-Trejos, E., Pérez-García, E. A., Meave, J. A., Bongers, F., \& Poorter, L. (2010). Functional traits and environmental filtering drive community assembly in a species-rich tropical system. Ecology, 91(2), 386398. https://doi.org/10.1890/08-1449.1

Leon, A. C., \& Heo, M. (2009). Sample sizes required to detect interactions between two binary fixed-effects in a mixed-effects linear regression model. Computational Statistics \& Data Analysis, 53(3), 603-608. https://doi.org/10.1016/j.csda.2008.06.010

Lesica, P., \& Shelly, J. S. (1992). Effects of cryptogamic soil crust on the population dynamics of Arabis fecunda (Brassicaceae). The American Midland Naturalist, 128, 53-60, https://doi.org/10.2307/2426412

Levine, J. M., Adler, P. B., \& Yelenik, S. G. (2004). A meta-analysis of biotic resistance to exotic plant invasions. Ecology Letters, 7(10), 975-989. https://doi.org/10.1111/j.1461-0248.2004.00657.x

Li, X. R., Zhang, P., Su, Y. G., \& Jia, R. L. (2012). Carbon fixation by biological soil crusts following revegetation of sand dunes in arid desert regions of China: A four-year field study. Catena, 97, 119-126. https ://doi.org/10.1016/j.catena.2012.05.009

Liancourt, P., Callaway, R. M., \& Michalet, R. (2005). Stress-tolerance and competitive-response ability determine the outcome of biotic interactions. Ecology, 86, 1611-1618. https://doi.org/10.1890/04-1398

Lortie, C. J., Brooker, R. W., Choler, P., Kikvidze, Z., Michalet, R., Pugnaire, F. I., \& Callaway, R. M. (2004). Rethinking plant community theory. Oikos, 107(2), 433-438. https://doi. $\operatorname{org} / 10.1111 / \mathrm{j} .0030-1299.2004 .13250 . x$

Luzuriaga, A. L., Sánchez, A. M., Maestre, F. T., \& Escudero, A. (2012). Assemblage of a semi-arid annual plant community: Abiotic and biotic filters act hierarchically. PLoS ONE, 7(7), e41270. https://doi. org/10.1371/journal.pone.0041270

Maestre, F. T., Bowker, M. A., Escolar, C., Puche, M. D., Soliveres, S., Maltez-Mouro, S., ... Escudero, A. (2010). Do biotic interactions modulate ecosystem functioning along stress gradients? Insights from semi-arid plant and biological soil crust communities. Philosophical Transactions of the Royal Society of London B: Biological Sciences, 365(1549), 2057-2070. https://doi.org/10.1098/rstb.2010.0016

Maestre, F. T., Callaway, R. M., Valladares, F., \& Lortie, C. J. (2009). Refining the stress-gradient hypothesis for competition and facilitation in plant communities. Journal of Ecology, 97(2), 199-205. https:// doi.org/10.1111/j.1365-2745.2008.01476.x

Maestre, F. T., Escolar, C., de Guevara, M. L., Quero, J. L., Lázaro, R., Delgado-Baquerizo, M., ... Gallardo, A. (2013). Changes in biocrust cover drive carbon cycle responses to climate change in drylands. Global Change Biology, 19(12), 3835-3847. https://doi.org/10.1111/ gcb.12306 
McCluney, K. E., Belnap, J., Collins, S. L., González, A. L., Hagen, E. M., Nathaniel Holland, J., ... Wolf, B. O. (2012). Shifting species interactions in terrestrial dryland ecosystems under altered water availability and climate change. Biological Reviews, 87(3), 563-582. https:// doi.org/10.1111/j.1469-185X.2011.00209.x

McGill, B. J., Enquist, B. J., Weiher, E., \& Westoby, M. (2006). Rebuilding community ecology from functional traits. Trends in Ecology \& Evolution, 21(4), 178-185. https://doi.org/10.1016/j.tree.2006. 02.002

Megill, L., Walker, L. R., Vanier, C., \& Johnson, D. (2011). Seed bank dynamics and habitat indicators of Arctomecon californica, a rare plant in a fragmented desert environment. Western North American Naturalist, 71(2), 195-205. Retrieved from https://www.jstor.org/ stable/41718137

Michalet, R., Brooker, R. W., Cavieres, L. A., Kikvidze, Z., Lortie, C. J., Pugnaire, F. I., ... Callaway, R. M. (2006). Do biotic interactions shape both sides of the humped-back model of species richness in plant communities? Ecology Letters, 9(7), 767-773. https://doi. org/10.1111/j.1461-0248.2006.00935.x

Miller, J. E., \& Damschen, E. I. (2017). Biological soil crust cover is negatively related to plant richness in Ozark sandstone glades. Journal of the Torrey Botanical Society, 144(2), 170-178. https://doi. org/10.3159/TORREY-D-15-00076

Miranda, J. D. D., Armas, C., Padilla, F. M., \& Pugnaire, F. I. (2011). Climatic change and rainfall patterns: Effects on semi-arid plant communities of the Iberian Southeast. Journal of Arid Environments, 75(12), 13021309. https://doi.org/10.1016/j.jaridenv.2011.04.022

Morgan, J. W. (2006). Bryophyte mats inhibit germination of nonnative species in burnt temperate native grassland remnants. Biological Invasions, 8(2), 159-168. https://doi.org/10.1007/ s10530-004-2881-y

Nakagawa, S. (2015). Missing data: Mechanisms, methods and messages. In Fox, G. A., Negrete-Yankelevich, S. \& Sosa, V. J. (Eds.), Ecological statistics: Contemporary theory and application (pp. 81-105). Oxford, UK: Oxford University Press.

New, M., Lister, D., Hulme, M., \& Makin, I. (2002). A high-resolution data set of surface climate over global land areas. Climate research, 21(1), $1-25$.

Noble, I. R., \& Slatyer, R. O. (1977). Post-fire succession of plants in Mediterranean ecosystems [Eucalyptus]. USDA Forest Service General Technical Report WO.

Oosting, H. J. (1948). The study of plant communities: an introduction to plant ecology. San Francisco, CA: W.H. Freeman.

Pan, Z., Pitt, W. G., Zhang, Y., Wu, N., Tao, Y., \& Truscott, T. T. (2016). The upside-down water collection system of Syntrichia caninervis. Nature Plants, 2(7), 16076. https://doi.org/10.1038/nplants. 2016.76

Pearcy, R. W., \& Ehleringer, J. (1984). Comparative ecophysiology of C3 and C4 plants. Plant, Cell, and Environment, 7(1), 1-13. https://doi. org/10.1111/j.1365-3040.1984.tb01194.x

Pendleton, R. L., Pendleton, B. K., Howard, G. L., \& Warren, S. D. (2003). Growth and nutrient content of herbaceous seedlings associated with biological soil crusts. Arid Land Research and Management, 17(3), 271-281. https://doi.org/10.1080/15324980301598

Peralta, A. M. L., Sánchez, A. M., Luzuriaga, A. L., \& Escudero, A. (2016). Factors driving species assemblage in Mediterranean soil seed banks: From the large to the fine scale. Annals of Botany, 117(7), 1221-1228. https://doi.org/10.1093/aob/mcw039

Peterson, E. B. (2013). Regional-scale relationship among biological soil crusts, invasive annual grasses, and disturbance. Ecological Processes, 2(1), 2. https://doi.org/10.1186/2192-1709-2-2

Prasse, R., \& Bornkamm, R. (2000). Effect of microbiotic soil surface crusts on emergence of plants. Plant Ecology, 150(1-2), 65-75. https ://doi.org/10.1023/A:1026593429455
Prăvălie, R. (2016). Drylands extent and environmental issues. A global approach. Earth-Science Reviews, 161, 259-278. https://doi. org/10.1016/j.earscirev.2016.08.003

R Core Development Team. (2017). R: A language and environment for statistical computing. Vienna, Austria: R Foundation for Statistical Computing. Retrieved from https://www.R-project.org/

Reed, S. C., Coe, K. K., Sparks, J. P., Housman, D. C., Zelikova, T. J., \& Belnap, J. (2012). Changes to dryland rainfall result in rapid moss mortality and altered soil fertility. Nature Climate Change, 2(10), 752. https://doi.org/10.1038/nclimate1596

Reisner, M. D., Grace, J. B., Pyke, D. A., \& Doescher, P. S. (2013). Conditions favouring Bromus tectorum dominance of endangered sagebrush steppe ecosystems. Journal of Applied Ecology, 50(4), 1039-1049. https://doi.org/10.1111/1365-2664.12097

Ridgeway, G., Southworth, M. H., \& Runit, S. (2013). Package 'gbm'. Viitattu, 10(2013), 40.

Rodriguez-Caballero, E., Belnap, J., Büdel, B., Crutzen, P. J., Andreae, M. O., Pöschl, U., \& Weber, B. (2018). Dryland photoautotrophic soil surface communities endangered by global change. Nature Geoscience, 11(3), 185. https://doi.org/10.1038/s41561-018-0072-1

Rosentreter, R., Eldridge, D. J., Westberg, M., Williams, L., \& Grube, M. (2016). Structure, composition, and function of biocrust lichen communities. In B. Webber, B. Büdel, \& J. Belnap (Eds.), Biological soil crusts: An organizing principle in drylands (pp. 121-138). Cham: Springer. https://doi.org/10.1007/978-3-319-30214-0_7

Sage, R. F., \& Kubien, D. S. (2007). The temperature response of C3 and C4 photosynthesis. Plant, Cell, and Environment, 30(9), 1086-1106. https://doi.org/10.1111/j.1365-3040.2007.01682.x

Schupp, E. W. (1995). Seed-seedling conflicts, habitat choice, and patterns of plant recruitment. American Journal of Botany, 82, 399-409. https://doi.org/10.1002/j.1537-2197.1995.tb12645.x

Serpe, M. D., Orm, J. M., Barkes, T., \& Rosentreter, R. (2006). Germination and seed water status of four grasses on moss-dominated biological soil crusts from arid lands. Plant ecology, 185(1), 163-178. https://doi. org/10.1007/s11258-005-9092-1

Scott, A. J., \& Morgan, J. W. (2012). Early life-history stages drive community reassembly in Australian old-fields. Journal of Vegetation Science, 23(4), 721-731. https://doi.org/10.1111/j.1654-1103.2011.01382.x

Soliveres, S., \& Maestre, F. T. (2014). Plant-plant interactions, environmental gradients and plant diversity: A global synthesis of communitylevel studies. Perspectives in Plant Ecology, Evolution and Systematics, 16(4), 154-163. https://doi.org/10.1016/j.ppees.2014.04.001

Song, G., Li, X., \& Hui, R. (2017). Effect of biological soil crusts on seed germination and growth of an exotic and two native plant species in an arid ecosystem. PLoS ONE, 12(10), e0185839. https://doi. org/10.1371/journal.pone.0185839

Souza-Egipsy, V., Ascaso, C., \& Sancho, L. G. (2002). Water distribution within terricolous lichens revealed by scanning electron microscopy and its relevance in soil crust ecology. Mycological Research, 106(11), 1367-1374. https://doi.org/10.1017/S0953756202006731

Staniczenko, P. P., Sivasubramaniam, P., Suttle, K. B., \& Pearson, R. G. (2017). Linking macroecology and community ecology: Refining predictions of species distributions using biotic interaction networks. Ecology Letters, 20(6), 693-707. https://doi.org/10.1111/ele.12770

Suding, K. N., Collins, S. L., Gough, L., Clark, C., Cleland, E. E., Gross, K. L., ... Pennings, S. (2005). Functional-and abundance-based mechanisms explain diversity loss due to $\mathrm{N}$ fertilization. Proceedings of the National Academy of Sciences of the United States of America, 102(12), 4387-4392. https://doi.org/10.1073/pnas.0408648102

Tighe, M., Haling, R. E., Flavel, R. J., \& Young, I. M. (2012). Ecological succession, hydrology and carbon acquisition of biological soil crusts measured at the micro-scale. PLoS ONE, 7(10), e48565. https://doi. org/10.1371/journal.pone.0048565

Tilman, D. (2004). Niche tradeoffs, neutrality, and community structure: a stochastic theory of resource competition, invasion, 
and community assembly. Proceedings of the National Academy of Sciences, 101(30), 10854-10861. https://doi.org/10.1073/ pnas.0403458101

Tucker, C. L., McHugh, T. A., Howell, A., Gill, R., Weber, B., Belnap, J., ... Reed, S. C. (2017). The concurrent use of novel soil surface microclimate measurements to evaluate $\mathrm{CO}_{2}$ pulses in biocrusted interspaces in a cool desert ecosystem. Biogeochemistry, 135(3), 239-249. https://doi.org/10.1007/s10533-017-0372-3

Van Der Heijden, M. G., Bardgett, R. D., \& Van Straalen, N. M. (2008). The unseen majority: Soil microbes as drivers of plant diversity and productivity in terrestrial ecosystems. Ecology Letters, 11(3), 296-310. https://doi.org/10.1111/j.1461-0248.2007.01139.x

Van der Putten, W. H., Macel, M., \& Visser, M. E. (2010). Predicting species distribution and abundance responses to climate change: Why it is essential to include biotic interactions across trophic levels. Philosophical Transactions of the Royal Society B: Biological Sciences, 365(1549), 2025-2034. https://doi.org/10.1098/rstb.2010.0037

VanKleunen, M.,Weber,E., \& Fischer,M.(2010).Ameta-analysis oftraitdifferences between invasive and non-invasive plant species. Ecology Letters, 13(2), 235-245. https://doi.org/10.1111/j.1461-0248.2009.01418.x

Viechtbauer, W. (2010). Conducting meta-analyses in R with the metafor package. Journal of Statistical Software, 36(3), 1-48. Retrieved from http://www.jstatsoft.org/v36/i03/

Vitousek, P. M., Menge, D. N., Reed, S. C., \& Cleveland, C. C. (2013). Biological nitrogen fixation: Rates, patterns and ecological controls in terrestrial ecosystems. Philosophical Transactions of the Royal Society B: Biological Sciences, 368(1621), 20130119. https://doi.org/10.1098/ rstb.2013.0119

West, N. E. (1990). Structure and function of microphytic soil crusts in wildland ecosystems of arid to semi-arid regions. Advances in Ecological Research, 20, 179-223. https://doi.org/10.1016/S0065-2504(08)60055-0

Wisz, M. S., Pottier, J., Kissling, W. D., Pellissier, L., Lenoir, J., Damgaard, C. F., ... Svenning, J.-C. (2013). The role of biotic interactions in shaping distributions and realised assemblages of species: Implications for species distribution modelling. Biological Reviews, 88(1), 15-30. https://doi.org/10.1111/j.1469-185X.2012.00235.x

Zaady, E., Gutterman, Y., \& Boeken, B. (1997). The germination of mucilaginous seeds of Plantago coronopus, Reboudia pinnata, and Carrichtera annua on cyanobacterial soil crust from the Negev Desert. Plant and Soil, 190, 247-252. https://doi.org/10.1023/A:1004269031844

Zhang, Y. M., Aradottir, A. L., Serpe, M., \& Boeken, B. (2016). Interactions of biological soilcrusts with plants. In B. Webber, B. Büdel, \& J. Belnap (Eds.), Biological soil crusts: An organizing principle in drylands (pp. 385-406). Cham: Springer. https://doi. org/10.1007/978-3-319-30214-0_1

Zhang, Y. M., \& Belnap, J. (2015). Growth responses of five desert plants as influenced by biological soil crusts from a temperate desert. China. Ecological Research, 30(6), 1037-1045. https://doi.org/10.1007/ s11284-015-1305-z

Zhang, Y., Nan, W. U., Zhang, B., \& Zhang, J. (2010). Species composition, distribution patterns and ecological functions of biological soil crusts in the Gurbantunggut Desert. 干旱区科学, 2(3), 180-189.

Zhang, Y. M., \& Nie, H. L. (2011). Effects of biological soil crusts on seedling growth and element uptake in five desert plants in Junggar Basin, western China. Chinese Journal of Plant Ecology, 35, 380-388. https://doi.org/10.3724/sp.j.1258.2011.00380

Zhang, Y. M., Wang, H. L., Wang, X. Q., Yang, W. K., \& Zhang, D. Y. (2006). The microstructure of microbiotic crust and its influence on wind erosion for a sandy soil surface in the Gurbantunggut Desert of Northwestern China. Geoderma, 132(3), 441-449. https://doi. org/10.1016/j.geoderma.2005.06.008

\section{SUPPORTING INFORMATION}

Additional supporting information may be found online in the Supporting Information section at the end of the article.

How to cite this article: Havrilla CA, Chaudhary VB, Ferrenberg S, et al. Towards a predictive framework for biocrust mediation of plant performance: A meta-analysis. J Ecol. 2019;107:2789-2807. https://doi.org/10.1111/13652745.13269 